\title{
Insider Trading: What Really Protects U.S. Investors?
}

\author{
Roger M. White ${ }^{\circledR *}$
}

\begin{abstract}
I examine the ability of the U.S. investor protection regime to limit insider trading returns, absent Section 16(b) of the Securities Exchange Act of 1934 (the short-swing rule). I find that in this setting, U.S. insiders execute short-swing trades that i) beat the market by approximately 15 basis points per day and ii) systematically divest ahead of disappointing earnings announcements. These results indicate that the bright-line rule restricting shorthorizon round-trip insider trading plays a substantial role in protecting outside investors from privately informed insiders in the United States.
\end{abstract}

\section{Introduction}

Insiders of publicly traded corporations typically have information advantages over outside investors when it comes to trading in their corporations' stocks. This is widely understood, and a large literature has evolved that examines the frequency, profitability, and regulations involved in insider trading. The consensus of this stream of research is that U.S. insiders tend to beat the market by a small but significant margin (e.g., $3 \%$ to $4 \%$ per year) and are curbed from reaping more substantial (information-based) profits by the threat of regulatory enforcement and class-action lawsuits, which can result in fines, prison sentences, and civil penalties.

U.S. law limits insider trading in two principal ways. The better known limit prohibits all traders from profiting from private information (Section 10b5 of the

*White, roger.white@asu.edu, Arizona State University W. P. Carey School of Business. For feedback that greatly improved this manuscript, I thank my dissertation committee members at Emory University: Ilia Dichev (chair), Clifton Green, and Ed Owens. I am also grateful for helpful feedback from Bernard Black (the referee), Olivia Burnsed, Jivas Chakravarthy, Suman Chattopadhyay, Jesse Ellis, Jarrad Harford (the editor), Bright Hong, In Do Hwang (discussant), Weishi Jia, Lisa LaViers, Melanie Millar, Robert Mocadlo, Shiva Rajgopal, Tom Shohfi, Han Stice, Charles Trzcinka, Devin Williams, Dan Zhou, and workshop participants at Emory University, Yale University, Southern Methodist University, Penn State University, Arizona State University, the University of Illinois, and the 2016 Midwest Finance Association annual meeting. Chip Presten (Baker, Donelson, Bearman, Caldwell \& Berkowitz) and Urska Velikonja (Georgetown University School of Law) also provided their invaluable institutional knowledge, for which I am thoroughly indebted and appreciative. 
Securities Exchange Act of 1934) and has been often studied. ${ }^{1}$ However, it was not until the 1960s that Section 10b5 was first interpreted to apply to insiders' securities trades. Before this, insider trading in the United States was federally regulated only by Section 16(b) of the Securities Exchange Act of 1934 (Seligman (2003)). Section 16(b) bars insiders from profiting from "short-swing" trades, defined as a buy followed by a sale within 6 months or vice versa. Any profits from shortswing trades must be returned to the firm. Insiders must report all trades to the U.S. Securities and Exchange Commission (SEC) on Forms 3 and 4, so violations of this mechanical rule are apparent and quickly remedied. A cadre of lawyers enforces 16(b) compliance by scouring these filings for apparent violations of the rule, including its technical aspects (e.g., Goldstein (2017), Anthony (2014), and Taylor (1997)).

In this article, I exploit an exception to Section 16(b) to examine two related questions about how U.S. securities markets function in the absence of shortswing insider trading prohibitions: How well does the remainder of the insider trading regulatory framework protect outside investors from insider trading? How large are the information advantages of U.S. corporate insiders?

My empirical strategy involves a loophole in the judicial interpretation of Section 16(b). Specifically, U.S. judges have ruled, since the 1940s, that 16(b) applies only to single classes of securities. If a firm has multiple classes of traded securities, it is permissible under 16(b) for an insider to profit from buying class A shares today and selling class B shares in 2 months. I build a sample of such trades by U.S. insiders and refer to these trades as pseudo short-swing insider trades. This setting limits my sample to a few dozen firms and approximately 1,000 trades (i.e., firms that have more than one liquid class of stock). Although this sample is economically insignificant in its own right (even if all the trades were based on private insider information), the setting is informative in that it illuminates the effectiveness of the remaining U.S. rules governing insider trades, absent a bright-line rule.

That is, although not a perfect counterfactual, this analysis offers insight into i) a world in which the SEC, Rule 10b5, state regulators, and the class-action system stand to protect outside investors, absent a blanket prohibition on shortswing insider trading, and ii) the ability of insiders to profit from trading in such a regime.

I find that when the short-swing restriction fails to bind, U.S. insiders can earn considerable returns when trading in their own firms' stocks. On average, buy-sell pseudo short-swing insider trades earn abnormal returns of approximately 20 basis points per day between the two trades, and sell-buy trades avoid (abnormal) losses of approximately 10 basis points per day. The typical buy-first, sell-later trade spans approximately 105 days and generates excess returns (excess dollar profits) on the order of $10 \%(\$ 30,000)$. Short-swing trades beginning with a sell tend to have shorter intervals between the opening and closing transaction

${ }^{1}$ This includes research in finance examining the returns to insider trades (e.g., Jagolinzer, Larcker, and Taylor (2011), Jagolinzer (2008), Brochet (2010), Ke, Huddart, and Petroni (2003), and Jeng, Metrick, and Zeckhauser (2003)) as well as commentaries in law reviews about the efficacy, application, and validity of the statute (e.g., Black (2001), Bucklo (1977), Swanson (2003), Ferrell and Saha (2011), and Muth (2009)). 
(mean $=86$ days) but generate overall excess returns of similar magnitude $(-9 \%$, with abnormal dollar profits on the order of $\$ 6,000)$. By comparison, the returns observed in typical insider trading settings in the United States are smaller by an order of magnitude (on an excess return per day level).

Broadly, these results indicate that without support from a bright-line rule prohibiting insiders from profiting from short-swing trades (i.e., Section 16(b)), the remaining insider trading regulations are unable to prevent U.S. insiders from reaping profits by trading with outside investors via short-horizon transactions.

I expect these results to directly inform three streams of literature. First, they demonstrate that it is not a well-funded securities regulator, common law origin, or class-action system that (alone or together) protects U.S. outside investors from exploitative insider trading. Although these are valuable protections, they are not sufficient in the absence of a bright-line rule prohibiting short-horizon investing by insiders. Rather, they are part of a framework that, with the short-swing insider trading prohibition, combine to provide such protection. ${ }^{2}$ My results illustrate that unraveling a single (often-overlooked) strand from that regulatory framework could greatly enhance the ability of U.S. insiders to extract wealth from uninformed outside investors. Securities regulators abroad should note that this finding suggests that a short-swing prohibition is an important factor in the success of U.S. markets, at least in terms of protecting and encouraging outside investment.

Second, my results offer insight into the short-horizon informational advantages of U.S. insiders. The literature has been largely restricted to examining information advantages in long-term trading by insiders (i.e., trades not forbidden by 16 (b)), whereas my results illuminate the potential profits insiders could earn if permitted to trade both ways in their firms' stock over short periods. If anything, my results indicate a lower bound to such profitability, in that short-swing trading in a single class of security would likely be considerably easier than the cross-class swing trading I exploit.

Third and finally, Section 16(b) has been the topic of considerable debate in the securities law literature. Opponents brand it as irrational, inefficient, and insignificant given the strength of the rest of the U.S. investor protection regime (e.g., O'Connor (1989), Manne (2008)), whereas supporters call it one of the most important protections in U.S. capital markets (Macchiarola (2014)). There have even been three advanced campaigns to repeal Section 16(b), the last and most serious of which occurred in 1995 and was undone only by a lukewarm endorsement of Section 16(b) by the SEC (Romeo and Dye (2000)). My findings suggest what short-swing insider trades would look like if Section 16(b) were to be repealed, and this counterfactual is unlikely to be attractive to outside investors in the United States.

The article proceeds as follows: Section II reviews the literatures on insider trading and securities regulation. Section III describes my empirical approach. Section IV reports my results, and Section V provides robustness tests. Section VI concludes.

\footnotetext{
${ }^{2}$ In a similar vein, Black (2001) provides an excellent discussion of the combination of different regulatory elements necessary for efficient and protective securities markets.
} 


\section{Background and Literature Review}

Why do outside investors willingly participate in securities markets, like those in the United States, in which informed insiders also can buy and sell? A long literature in insider trading and securities regulation suggests that the answer lies in the ability of securities regulators and courts to protect outsiders from exploitative trading by insiders. A recurring theme in this literature is that the credit goes to a prohibition on insider trading on private, price-relevant information, enforced by a strong regulator and securities class-action framework, all in a common-law-based legal environment.

This conclusion is certainly believable, given the relatively modest abnormal returns earned by U.S. insiders. Although trading by U.S. corporate insiders is typically profitable, research finds that insiders beat the market by approximately $4 \%$ per year when trading in their firms' stock (e.g., Wang, Shin, and Francis (2012), Jeng et al. (2003)). Recent research has also identified types of insider trades that tend to be more profitable, such as unplanned trades (Cohen, Malloy, and Pomorski (2012), Amel-Zadeh, Faasse, and Lotz (2018)), ${ }^{3}$ which earn abnormal returns of approximately $18 \%$ per year, which is high, but perhaps not extravagantly so.

Although the finance and securities law literatures have long argued whether insider trading should be regulated at all (e.g., Manne (1966), Kyle (1985), Cornell and Sirri (1992), and Cao, Field, and Hanka (2004)), most regulatory agencies have prohibited insider trading on private, price-relevant information to encourage outside investors to participate in financial markets, lessen the risk of adverse selection, and improve liquidity and market efficiency (see Chung and Charoenwong (1998), Fishman and Hagerty (1992), Seyhun (1986), Fishe and Robe (2004), Ausubel (1990), DeMarzo, Fishman, and Hagerty (1998), and Fernandes and Ferreira (2009)). The enforcement of such provisions predicts decreasing cost of capital and increasing participation by investors and analysts (e.g., Bhattacharya and Daouk (2002), Christensen, Hail, and Leuz (2016), Maug, Van Halteren, and Ackerman (2008), and Bushman, Piotroski, and Smith (2005)).

In the United States, this regulation was introduced in the aftermath of several insider trading scandals in the 1960s, as regulators broadened the scope of Rule $10 \mathrm{~b} 5$ to apply to the securities transactions of corporate insiders (Seligman (2003)). Enforcement is instigated by either SEC enforcement staff or harmed investors, who act as plaintiffs in civil suits, generally class actions (Carangelo, Ferrillo, Schwartz, and Altemeier (2012)). Two important factors must be established for insiders to be held liable under 10b5. The first is guilt/fraudulent intent (scienter in legal parlance), which requires that the plaintiff/prosecutor prove that the insider knowingly used private, material information to profit from trades with outsiders. The second factor is that the information must be private and material. These requirements can make for difficult legal work for plaintiffs and prosecutors, particularly proving fraudulent intent. As a result, these cases are infrequent, with the SEC typically bringing Rule $10 \mathrm{~b} 5$ insider-trading enforcement actions approximately 50 times per year (Sokenuai et al. (2015)) and civil litigants filing

\footnotetext{
${ }^{3}$ Trading following regular calendar patterns indicates a preestablished $10 \mathrm{~b} 5-1$ plan, in which insiders commit to buying or selling firm stock according to a schedule.
} 
Rule 10b5 class-action lawsuits alleging insider trading approximately 30 times per year (Comolli and Starykh (2015)). ${ }^{4}$

This difficulty in bringing Rule $10 \mathrm{~b} 5$ actions has been widely recognized as a weakness in the current regulatory framework (e.g., Swanson (2003), Lowenfels (1978), Talesnick (1972), and Bucklo (1977)). Still, Rule 10b5 is sometimes credited with curbing high insider trading profits on its own, without mention of Section 16(b) (e.g., Dessent (1999), O’Connor (1989), and Easterbrook and Fischel (1991)).

What is credited with supporting the success of the current regulatory regime, specifically Rule 10b5, is a strong enforcement system. This primarily consists of criminal enforcement via the SEC (and Department of Justice) and civil enforcement via the plaintiffs' bar in the securities class-action system. The protection provided by the SEC is attributed to the (relatively) high levels of funding and staffing the agency receives. ${ }^{5}$ The literature intuitively ascribes the efficacy of regulatory policing to the staffing and resources available to regulators, with more staff and more funding generally leading to better protection of outside investors (Christensen et al. (2016), Jackson and Roe (2009)). In addition to SEC enforcement, the plaintiffs' bar can litigate potential Rule 10b5 violations in securities class-action lawsuits. The U.S. securities class-action system is well developed and widely viewed as acting as an additional check on insider trading and other corporate malfeasance (e.g., Field, Lowry, and Shu (2005), Cheng, Huang, Li, and Lobo (2010)).

Underlying the importance of legal and regulatory restraints on insider trading is the common law legal system in place in the United States. La Porta, Lopezde-Silanes, Shleifer, and Vishny (1998) and the substantial line of research that follows this study indicate that common law countries consistently do a better job of regulating securities markets and protecting investors (relative to countries with civil law legal origins). This is normally attributed to common law systems being more flexible, which permits judges latitude to protect investors against managerial malfeasance that is perhaps not directly prohibited by statutes or case law (La Porta, Lopez-de-Silanes, Shleifer, and Vishny (2000), Black (2001), and Seyhun (1992)).

Rarely is the short-swing prohibition (Section 16(b)) studied empirically or described as important, and some discussions are critical of the rule's value (e.g., Dessent (1999), O’Connor (1989), Manne (2008), Kahn and Winton (1998), and Lenkey (2017)). However, the short-swing prohibition does provide a clear, rules-based restriction that is easy to observe and enforce (the advantages of a bright-line rule; see Glaeser and Shleifer (2002)). Unfortunately, it is impossible to ascertain the number of legal actions taken in conjunction with Section 16(b), as most are never filed in court (but quickly settled before a filing, as liability is easy to establish). It is also impossible to detect how much the existence of

\footnotetext{
${ }^{4}$ Furthermore, approximately half of these civil cases are dismissed.

${ }^{5}$ Although some observers may feel that the SEC is underfunded given its mission, there is little debating the fact that, compared to securities regulators abroad, it is both staffed and funded at high levels (see Jackson and Roe (2009)).
} 
Section 16(b) deters short-swing insider trading, as potential trades so affected simply do not exist. ${ }^{6}$

In this article, I examine the performance of the insider-trading regulatory framework absent Section 16(b). In this setting, the components of the regulatory framework that research has focused on are still in place and unchanged (i.e., Rule 10b5, SEC funding and staffing, threat of securities class-action lawsuits, common law origin of the U.S. legal system, etc.). The main contribution of this article is its examination of insider trading profits in a setting devoid of Section 16(b), which allows me to provide evidence of the effect of the remaining regulatory framework to protect outside investors. If this remainder of the regulatory framework provides the bulk of protection for outside investors (as predicted elsewhere), the insider trading profits in my setting should resemble those in conventional settings.

Chen, Guan, and Ke (2014) conduct the closest study to mine in that they examine the returns to short-swing insider trading in Hong Kong. They find that short-swing trades (within a single class of stock) constitute $12 \%$ of insider trades and that these trades earn approximately $16 \%$ abnormal returns annually, relative to approximately $8 \%$ for conventional insider trades (in Hong Kong). Although this result is informative, its applicability to the United States is limited by the differences between the United States and Hong Kong in terms of regulator strength (Jackson and Roe (2009)) $)^{7}$ and the efficacy of securities class-action lawsuits, which both provide stronger checks on insider trading in the United States (Hong Kong law does not permit investor class-action lawsuits; see Johnstone (2015)). However, this result indicates that insiders are willing to trade in both directions over a short horizon to reap trading profits.

\section{Empirical Approach}

Clearly, I cannot follow the Chen et al. (2014) approach in the United States, as profitable short-swing insider trades are restricted by Section 16(b) of the Securities Exchange Act of 1934. However, a legal quirk has created an opportunity to evaluate a counterfactual sample of short-swing insider trades within the United States. Specifically, the judicial interpretation of Section 16(b) is that

\footnotetext{
${ }^{6}$ In an effort to be concise, I omit from the main text much of the institutional detail about how Section 16(b) is enforced in civil courts. Briefly, the plaintiffs' bar monitors all insider transactions, which are filed with the SEC and searchable online. When a profitable short-swing insider trade is observed (Tamersoy et al. (2014) observe that such trades are not uncommon), a representative of the plaintiff attorney typically buys a small stake in the offending firm (just 1 share is sufficient). The plaintiff attorney then sends a letter to the firm and insider asking that the profits of the trade be returned to the corporate treasury and that the firm adequately compensate the plaintiff attorney for providing this monitoring on behalf of the outside shareholders (plaintiff attorneys' remuneration typically falls between $10 \%$ and $50 \%$ of recovered profits). Only rarely do these actions actually end up being filed and taken to court, as there is no viable legal defense in cases where a profitable shortswing insider trade has occurred (i.e., violation is assessed by strict liability, so there is no need for the plaintiffs to show fraudulent intent, only the existence of a profitable trade). As a result, the vast majority of enforcement and deterrence brought about by Section 16(b) is unobservable to outside parties. For further detail, see Dessent (1999), Agrawal and Jaffe (1995), and O'Connor (1989).

${ }^{7}$ Levin, N. "Alibaba's Spurning of Hong Kong Listing Has Downsides." Wall Street Journal (Mar. 18, 2014), https://blogs.wsj.com/moneybeat/2014/03/18/alibabas-spurning-of-hong-konglisting-has-downsides/.
} 
the short-swing insider trading prohibition applies to individual securities but not across securities for the same firm. Accordingly, it is legal for an insider to retain the profits derived from purchasing class A stock today and selling class B stock next week. This judicial interpretation has been upheld consistently since 1943 (Smolowe v. Delendo Corporation (1943)) and confirmed as recently as 2013 (Gibbons v. Malone (2011)). ${ }^{8}$ In effect, this allows for short-swing insider trading across different classes of stock, the returns of which are usually highly correlated (at $\rho \approx 0.85$ levels when measured monthly in my sample; see Table 4 later).

I exploit this judicial interpretation and examine short-swing insider trading in firms that have multiple classes of publicly traded stocks. For insiders in multiclass firms that trade in both share classes, I construct pseudo short-swing insider trades, as described previously (e.g., buy class A stock today and sell class B stock within 6 months or vice versa).

I analyze the profitability of such trades to determine the degree to which the remainder of the insider trading regulatory framework protects outside investors from informed insiders. If these pseudo short-swing insider trades substantially outperform conventional insider trades, this provides evidence that i) the elements of insider trading regulation emphasized in prior research are not as protective as previously thought and ii) Section 16(b) provides measurable value.

I first build a sample of pseudo short-swing insider trades by matching every insider transaction in the Thomson Reuters Insider Filings Data Feed to other transactions by the same insider in securities with the same 6-digit CUSIP (which denotes issuer/firm identity) but with different 7 th and 8th digits (which denote specific issues/classes of stock). If these transactions are within 6 months of each other and in opposite directions (buy/sell), they qualify as pseudo short-swing insider trades. According to Section 16(b), it is illegal for insiders to profit from these trades if they occur in the same class of security.

I have two dates for each pseudo short-swing insider trade: the opening date and the closing date. The opening date is not identifiable ex ante. For example, consider an insider who has made no transactions in any of the firm's stock in the last year but buys class A stock in Jan. 2010. In Mar. 2010, the insider sells some of the firm's class B stock. At that point, the Jan. 2010 buy (of class A stock) is identifiable as the opening of a short-swing trade, and the Mar. 2010 date is identifiable as the closing date of the short-swing trade.

I examine the abnormal returns earned between these opening and closing trades (similar to Chen et al. (2014)), which I refer to as the pseudo short-swing interval. $^{9}$ Any abnormal return earned over this interval is returned to the firm except for the multiclass loophole in Section 16(b). Observing sizable abnormal returns over this interval indicates that the bright-line prohibition on short-swing insider trading (Section 16(b)) offers incremental protection for outside investors beyond that of Rule $10 \mathrm{~b} 5$ and the rest of the current enforcement regime.

\footnotetext{
${ }^{8}$ See Liman (2013), Goldmark (2013), and Finn and Markus (2013) for thorough discussions of Gibbons v. Malone (2011).

${ }^{9}$ Accordingly, I omit any pseudo short-swing insider trades that happen on the same day, as this interval is 0 days.
} 
I calculate abnormal returns on this interval using simple market-adjusted returns, the capital asset pricing model (CAPM; see Sharpe (1964)), and a Fama-French (1993) 4-factor model that incorporates the momentum factor from Carhart (1997). In the CAPM and Fama-French models, I estimate betas for the factors over the 4 quarters ending 2 trading days before the opening trade of the pseudo short-swing trade in question.

The underlying sample trades used in this analysis are drawn from the Thomson Reuters Insider Filings Data Feed. I examine only open market stock trades (i.e., the type of transactions affected by 16(b); see Richardson, Teoh, and Wysocki (2004)) that happen after the implementation of the Private Securities Litigation Reform Act (1995). ${ }^{10}$

Finally I note that in 1991, Section 16(b) was adjusted to remove the complications arising from option compensation (Richardson et al. (2004)). For my entire sample period (1996-2013), the only types of transactions I capture are open market stock trades. Insider options, stock grants, and the like are not included in this analysis but could be of future interest, as such transactions allow for similar pseudo short-swing trading.

\section{Results}

\section{A. Summary Statistics}

Table 1 reports summary statistics relating to the size of the pseudo-shortswing trades. The results allay any concern that the pseudo short-swing insider trades I observe are too small to attract the attention of the SEC or other elements of the securities regulatory regime. ${ }^{11}$ Table 1 reports that the mean pseudo short-swing trade that starts with a buy and ends with a sell involves a $\$ 460,000$ purchase of one class of a firm's stock, followed by a sell of $\$ 1.9$ million in another class. Likewise, the average sell-first, buy-later pseudo short-swing insider trade sees a $\$ 2.6$ million sell, followed by a $\$ 260,000$ buy. Median values are an

TABLE 1

Trade Size Summary Statistics

Table 1 reports summary statistics for pseudo short-swing insider trades. These are round-trip transactions (buy-sell or sell-buy) in different classes of securities for the same firm. For both buy-sell and sell-buy trades, I report mean and median values for the opening and closing trade that constitute the short-swing transaction. The data underlying these trades are drawn from the Thomson Reuters Insider Filings Data Feed.

\begin{tabular}{|c|c|c|c|}
\hline \multirow[b]{2}{*}{ Trade Type } & \multirow[b]{2}{*}{$N$} & \multicolumn{2}{|c|}{$\$$ Value } \\
\hline & & Mean & Median \\
\hline $\begin{array}{l}\text { Short-swing type: Buy first, sell later } \\
\text { Opening trade } \\
\text { Closing trade }\end{array}$ & 733 & $\begin{array}{l}\$ 460,775 \\
\$ 1,943,341\end{array}$ & $\begin{array}{l}\$ 16,200 \\
\$ 35,000\end{array}$ \\
\hline $\begin{array}{l}\text { Short-swing type: Sell first, buy later } \\
\text { Opening trade } \\
\text { Closing trade }\end{array}$ & 323 & $\begin{array}{l}\$ 2,648,199 \\
\$ 259,261\end{array}$ & $\begin{array}{l}\$ 27,150 \\
\$ 18,690\end{array}$ \\
\hline
\end{tabular}

\footnotetext{
${ }^{10}$ Starting my sample in 1996 limits my data to a constant securities class-action regime, as the 1995 Private Securities Litigation Reform Act substantially increased the barriers to such litigation (Coffee (2006)).

${ }^{11}$ Necessary for $10 \mathrm{~b} 5$ enforcement.
} 
order of magnitude lower but still indicate sizable transactions. Figure 1 provides a histogram of these trade sizes (smaller of the two short-swing trades) by direction, and Figure 2 provides a histogram of the length of the pseudo short-swing insider trading intervals (i.e., number of days between opening and closing trades). Table 2 provides a first look at the dollar value excess profitability of these trades.

Although the size of these trades indicates that pseudo short-swing transactions are economically large enough to attract SEC attention (or attention from prosecutors or the civil attorneys of outside investors), the overall sample size is small. Note that these pseudo short-swing trades can only occur in firms that have at least two classes of stock with requisite liquidity for occasional trading (i.e., approximately $2 \%$ of firms on National Association of Securities Dealers Automated Quotation system (NASDAQ) and New York Stock Exchange (NYSE)). This results in only 1,056 pseudo short-swing insider trades entering my sample from 1996 to 2013. Table 1 reports the breakdown by direction. I observe 733 short-swing transactions of the buy-first, sell-later type, and 323 of the sell-first, buy-later type. Parts of some transactions are double counted in this analysis if, for example, an insider makes purchases on Feb. 1 and 2, followed by a sale on Feb. 5. This set of trades would enter my sample as two separate buy-first,

\section{FIGURE 1}

\section{Short-Swing Trade Size by Opening Trade Direction}

Figure 1 shows a histogram of the dollar values of the pseudo short-swing transactions that constitute my sample. This figure tabulates only the sizes of the lower of the two trades that make up the pseudo short-swing trade.

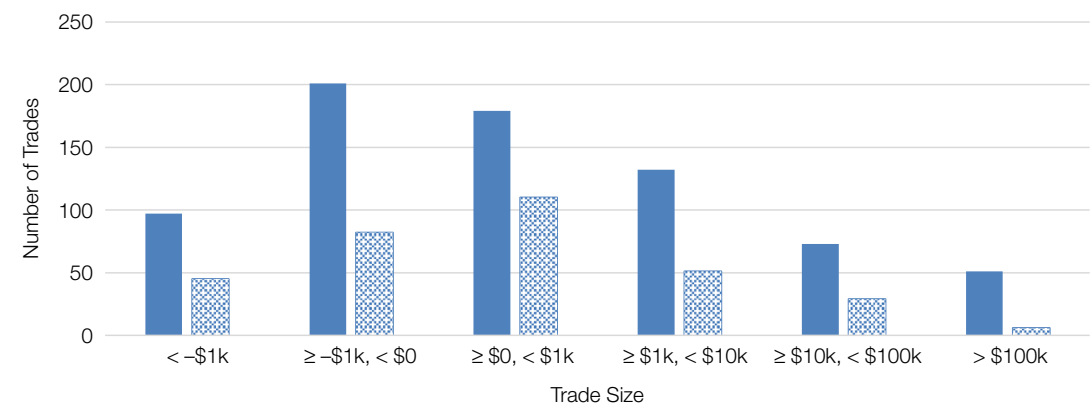

Buy First, Sell Later

\section{TABLE 2}

Profitability Summary Statistics

Table 2 reports summary statistics on the profitability of pseudo short-swing insider trades in my sample. These are round-trip transactions (buy-sell or sell-buy) in different classes of securities for the same firm. For both buy-sell and sell-buy trades, I report mean and median abnormal dollar profit values computed using a simple market adjustment and the smaller of the two short-swing transactions as the traded dollar amount. Negative values for sell-first, buy-later trades indicate losses avoided (profitable trades). The percentage of profitable trades is also reported (buy-first trades that earn abnormal profit and sell-first trades that avoid abnormal losses).

\begin{tabular}{|c|c|c|c|c|}
\hline \multirow[b]{2}{*}{ Trade Type } & \multirow[b]{2}{*}{ N } & \multicolumn{2}{|c|}{ Abnormal \$ Profits } & \multirow[b]{2}{*}{$\%$ Profitable } \\
\hline & & Mean & Median & \\
\hline Short-swing type: Buy first, sell later & 733 & $\$ 21,566.19$ & $\$ 129.76$ & $59.4 \%$ \\
\hline Short-swing type: Sell first, buy later & 323 & $-\$ 6,852.40$ & $-\$ 78.94$ & $60.7 \%$ \\
\hline
\end{tabular}




\section{FIGURE 2}

\section{Short-Swing Interval Length by Opening Trade Direction}

Figure 2 shows a histogram of the number of days between the opening trade and closing trade (in a different class) for the pseudo short-swing transactions that constitute my sample.

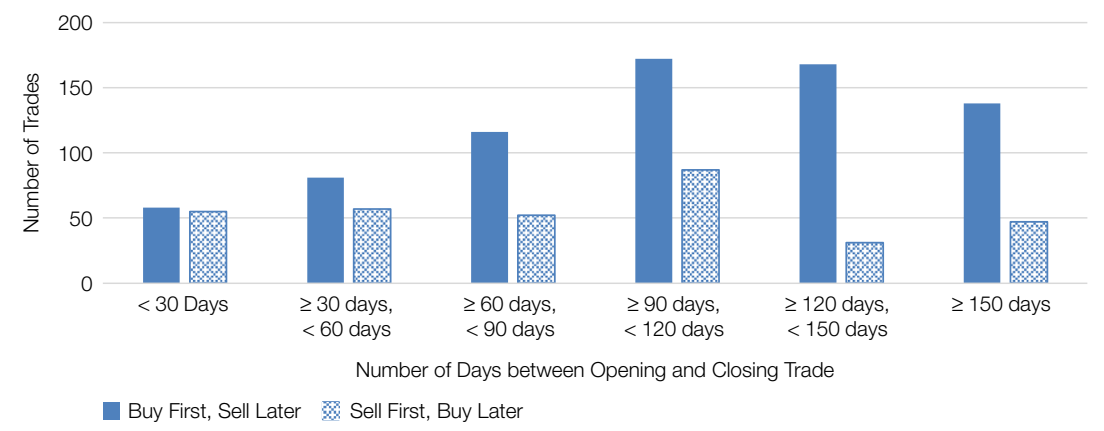

sell-later short-swing trades, and I correct for this double counting by clustering on (opening) trade in the event-study analysis. Alternate approaches yield a similar pattern of findings (i.e., keeping the shortest interval, longest interval, or highest dollar value trade), but smaller sample sizes sometimes result in weaker statistical significance. (See the Appendix for the most conservative of these sample adjustments.)

I tabulate the distribution of these trades across firms in Table 3. Forty-one firms enter this sample, suggesting that approximately $20 \%$ of firms with multiple (liquid) share classes see insiders conduct pseudo short-swing insider trading (at some point). This sample includes several firms that are household names, including Berkshire-Hathaway (34 pseudo short-swing insider trades), GeorgiaPacific (8), and Benihana (48). Other lesser known firms that contribute substantially to the sample include Heico (38 pseudo short-swing insider trades), International Speedway (59), Marsh Supermarkets (73), Reading International (432), and Waddell \& Reed (148). ${ }^{12}$ Table 3 also reports the year range over which pseudo short-swing insider trading is observed (earliest and most recent years). Notably, insiders at Heico are not only frequent but also longtime pseudo short-swing traders, with repeated transactions spanning more than a decade. ${ }^{13}$

\section{B. Properties of Multiclass Stocks}

As a preliminary check before moving to an examination of pseudo shortswing returns, I ensure that the different share classes of multiclass firms I examine are economic substitutes. I do so in two ways, first by examining cash

\footnotetext{
${ }^{12}$ Given the representation of Reading International and Waddell \& Reed in the sample, I confirm in untabulated robustness checks that omitting these observations leads to results of similar magnitude and statistical significance.

${ }^{13}$ For example, Heico's longtime CEO, Laurans Mendelson, has a habit of making 5- and 6-figure purchases of Heico stock before making 6- and 7-figure divestments in the opposite class. For instance, a \$423,000 investment in Heico Class A stock on Jan. 8, 2008, was quickly followed by divestments of Heico common stock of \$2 million (Jan. 14, 2008), \$1.3 million (Mar. 28, 2008), \$483,000 (Mar. 31, 2008), and \$1.2 million (Apr. 1, 2008).
} 
TABLE 3

Firm-Level Summary Statistics

Table 3 reports the number of pseudo short-swing insider trades per firm in my sample as well as the voting and dividend rights of the two most highly traded share classes for these firms. Reported in parentheses in the first column are the earliest and most recent years in which the firms' insiders engaged in pseudo short-swing insider trading (during the 1996-2013 sample period). a Operates as a holding company for two divisions, each of which is publicly traded (via tracking stocks) and individually decide dividend payouts. Voting power fluctuates with the ratio of each division's market value. ${ }^{b}$ Second class created during a takeover attempt. ${ }^{\circ}$ The only sample firm with more than two classes of stock involved in short-swing trading in the sample. Before 2003, multiple divisions of Genzyme operated with an individual

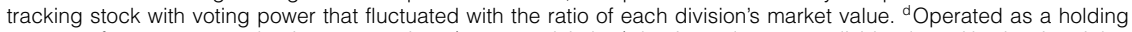
company for two separate business operations (paper and timber) that issued separate dividends and had voting rights that fluctuated as a function of relative market value. ${ }^{e}$ Subsequently delisted for failure to file timely $10-\mathrm{Q}$ and $10-\mathrm{K}$ reports with the U.S. Securities and Exchange Commission.

\begin{tabular}{|c|c|c|c|}
\hline Firm Name & $\begin{array}{c}\text { No. of Pseudo Short- } \\
\text { Swing } \\
\text { Insider Trades } \\
\end{array}$ & Voting Rights & Dividend Rights \\
\hline aron Rents Inc. (1996-2009) & 13 & Class B: Nonvoting & Class $\mathrm{B} \geq$ Class $\mathrm{A}$ \\
\hline Iberto Culver Co. (2003-2003) & 10 & Class A: $1 / 10$ th $\times$ Class B & Class $A \geq$ Class $B$ \\
\hline merican Greetings Corp. (1999-1999) & 2 & Class A: $1 / 10$ th $\times$ Class $B$ & Class A: $\overline{1} \times$ Class B \\
\hline pollo Group Inc. (2003-2004) & 4 & Class A: Nonvoting & Class A: $1 \times$ Class B \\
\hline erkin Elmer Corp. (1999-1999) & 3 & Fluctuating & Separate $^{\mathrm{a}}$ \\
\hline el Fuse Inc. (2012-2012) & 1 & Class B: Nonvoting & Class $A: 6 / 7$ th $\times$ Class $B$ \\
\hline enihana Inc. (2004-2008) & 48 & Class A: $1 / 10$ th $\times$ Class B & Class A: $1 \times$ Class B \\
\hline erkshire Hathaway Inc. (1999-2005) & 34 & Class A: $10,000 \times$ Class $B$ & Class A: $1,500 \times$ Class $B$ \\
\hline rown Forman Corp. (1996-2006) & 6 & Class B: Nonvoting & Class A: $1 \times$ Class $B$ \\
\hline entral Garden \& Pet Co. (2008-2008) & 9 & Class A: Nonvoting & Class $\mathrm{A}: 1 \times$ Class $\mathrm{B}$ \\
\hline ontinental Airlines Inc. (1998-1998) & 1 & Class A: $10 \times$ Class B & Not specified \\
\hline rawford \& Co. (1998-2003) & 6 & Class A: Nonvoting & Class $A \geq$ Class $B$ \\
\hline urtiss Wright Corp. (2004-2004) & 1 & Class $A: 1 / 4$ th $\times$ Class $B$ & Class A: $\overline{1} \times$ Class B \\
\hline onegal Group Inc. (2004-2005) & 2 & Class A: $1 / 10$ th $\times$ Class $B$ & Class A: $1.1 \times$ Class B \\
\hline X X Inc. (2003-2003) & 2 & Class A: $1 / 2 n d \times$ Class $B$ & Class A: $1 \times$ Class B \\
\hline Z Em Inc. (2002-2002) & 4 & Class B: Nonvoting & Class A: No dividends \\
\hline edders Corp. (1996-1997) & 3 & Class A: Nonvoting & Class A: $1 \times$ Class B \\
\hline rest City Enterprises Inc. (1995-2002) & 7 & Class $A: 1 / 3 r d \times$ Class $B$ & Class A: $1 \times$ Class B \\
\hline enentech Inc. (1999-1999) & 1 & Class $A: 1 \times$ Class $B$ & Class A: $1 \times{\text { Class } B^{b}}^{b}$ \\
\hline ienzyme Corp. (1995-2000) & 49 & Fluctuating & Not specified ${ }^{\mathrm{C}}$ \\
\hline eorgia Pacific Corp. (1999-2001) & 8 & Fluctuating & Separate $^{d}$ \\
\hline ay Television Inc. (2003-2004) & 10 & Class A: $10 \times$ Class B & Class A: $1 \times$ Class $B$ \\
\hline Greif Inc. (2002-2008) & 16 & Class A: Nonvoting & Class A: $2 \times$ Class B \\
\hline Heico Corp. (1998-2013) & 48 & Class $A: 1 / 10$ th $\times$ Class $B$ & Class A: $1 \times$ Class B \\
\hline D T Corp. (2002-2002) & 2 & Class A: $10 \times$ Class B & Class A: $1 \times$ Class B \\
\hline nterlink Electronics (2006-2006) & 2 & Not specified & Not specified ${ }^{e}$ \\
\hline ernational Speedway Corp. (2000-2003) & 59 & Class A: $1 / 5$ th $\times$ Class $B$ & Class A: $1 \times$ Class B \\
\hline Kelly Services Inc. (2004-2004) & 2 & Class A: Nonvoting & Class A: $1 \times$ Class B \\
\hline _ehman Brothers Holdings (1996-1996) & 1 & Class A: $1 \times$ Class B & Class A: Fixed dividend \\
\hline Marsh Supermarkets Inc. (2000-2005) & 73 & Class B: Nonvoting & Class A: $1 \times$ Class $B$ \\
\hline Molex Inc. (1996-1996) & 1 & Class A: Nonvoting & Class A: $1 \times$ Class B \\
\hline Moog Inc. (2000-2004) & 3 & Class A: $1 / 10$ th $\times$ Class $B$ & Class $A \geq$ Class $B$ \\
\hline Pacificare Health Systems Inc. (1997-1997) & 1 & Class B: Nonvoting & Class $A: \overline{1} \times$ Class $B$ \\
\hline Playboy Enterprises Inc. (2001-2001) & 1 & Class B: Nonvoting & Class A: Fixed Dividend \\
\hline Reading International (2000-2003) & 432 & Class A: Nonvoting & Not specified \\
\hline Rush Enterprises Inc. (2005-2006) & 2 & Class A: $1 / 20$ th $\times$ Class B & Class A: $1 \times$ Class B \\
\hline Seneca Foods Corp. (1999-2000) & 5 & Class A: $1 / 20$ th $\times$ Class $B$ & Class A: $1 \times$ Class B \\
\hline Sport Chalet Inc. (2006-2007) & 31 & Class A: $1 / 20$ th $\times$ Class B & Class A: $1.1 \times$ Class B \\
\hline Tecumseh Products Co. (2009-2009) & 1 & Class A: Nonvoting & Class A: $1 \times$ Class B \\
\hline Jrstadt Biddle Properties (2000-2011) & 4 & Class A: $1 / 20$ th $\times$ Class $B$ & Class $A: 1.1 \times$ Class $B$ \\
\hline Waddell \& Reed Financial (1999-2000) & 148 & Class A: $1 / 5$ th $\times$ Class B & Class A: $1 \times$ Class B \\
\hline
\end{tabular}

flow and voting rights per share class, and second by examining the correlations in returns across different classes of stock for the same firm. Table 3 reports the cash flow and voting rights of the different share classes for the firms in my sample. These data are collected from 10-K filings on the Electronic Data Gathering, Analysis, and Retrieval system (EDGAR). ${ }^{14}$

${ }^{14}$ Common dividend arrangements include equal dividends, defined and unequal dividends, undefined and unequal dividends (e.g., "if any dividends are issued then class A dividends must be greater than class B dividends"), and completely undefined dividends (denoted as "not specified"). 
The literature observes that most dual-class share structures were created to allow a founder, founding family, or senior management to retain voting control of the firm without needing to retain rights to a majority of the cash flows (DeAngelo and DeAngelo (1985), Amoako-Adu and Smith (2001), and Gompers, Ishii, and Metrick (2010)). The Table 3 data support this observation, in that the typical multiclass firm in my sample has a super-voting-type share (i.e., two types of common stock with different voting rights). Berkshire Hathaway is a well-known firm with such a structure, in that class A shares (BRK.A) have 1,500 times the cash flow (dividend) rights of class B shares, but 10,000 times the voting rights. Such an arrangement allows Warren Buffett (chief executive officer (CEO) and chairman) to maintain control of approximately $34 \%$ of the votes of Berkshire Hathaway while owning only $20 \%$ of the firm (by dollar value).

Despite these types of differences in dividends and votes, Table 4 reports that these different classes of shares for the same firm tend to have highly correlated returns. I conduct the analysis by examining the pairwise correlation in monthly returns for the Center for Research in Security Prices (CRSP) universe of multiclass firms in my sample period (1996-2013). For firms with more than two classes of stock, in the spirit of conservatism, I include the highest and lowest returns across multiple classes for that month (to prevent the correlation from being upwardly biased).

Table 4 reports the results of these correlations, with Pearson correlations above the diagonal and Spearman correlations below. Across this population, the pairwise Pearson correlation in monthly returns is approximately 0.85 (for both raw and market-adjusted returns), which is more than double the correlation between individual monthly stock returns and market returns (approximately 0.35, as observed in untabulated correlations where market returns are defined via equal weighting, value weighting, or the Standard \& Poor's (S\&P) 500 index). Similar findings obtain using the Spearman measures (below the diagonal in Table 4) and in untabulated correlations using daily returns. Although the results of Table 4

TABLE 4

Correlation of Stock Returns for Different Classes of Stock within Multiclass Firms

Table 4 reports the correlations between monthly returns in different securities issued by the same firm in the Center for Research in Security Prices (CRSP) population of multiclass firms during 1996-2013. The sample size of 12,694 refers to the number of firm-months in which multiple classes of securities were tradable (from 1996 to 2013). For firms with more than two traded securities, the highest and lowest monthly returns were used in the correlation to reduce any bias. Pearson correlations are reported above the diagonal, and Spearman correlations are reported below the diagonal. $p$-values are reported in square brackets beneath the correlation coefficients. $N=12,694$ (firm-months).

\begin{tabular}{|c|c|c|c|c|}
\hline \multirow[b]{2}{*}{ Return Type } & \multicolumn{2}{|c|}{$\begin{array}{l}\text { Multiclass Firm's } \\
\text { Monthly Return }\end{array}$} & \multicolumn{2}{|c|}{$\begin{array}{l}\text { Multiclass Firm's } \\
\text { Monthly Return } \\
\text { (market adjusted) }\end{array}$} \\
\hline & Highest & Lowest & Highest & Lowest \\
\hline $\begin{array}{l}\text { Multiclass firm's highest } \\
\text { monthly return }\end{array}$ & & $\begin{array}{r}0.84117 \\
{[<0.0001]}\end{array}$ & $\begin{array}{r}0.94928 \\
{[<0.0001]}\end{array}$ & $\begin{array}{r}0.78183 \\
{[<0.0001]}\end{array}$ \\
\hline $\begin{array}{l}\text { Multiclass firm's lowest } \\
\text { monthly return }\end{array}$ & $\begin{array}{r}0.86645 \\
{[<0.0001]}\end{array}$ & & $\begin{array}{r}0.77111 \\
{[<0.0001]}\end{array}$ & $\begin{array}{r}0.93526 \\
{[<0.0001]}\end{array}$ \\
\hline $\begin{array}{l}\text { Multiclass firm's highest } \\
\text { monthly return (market adjusted) }\end{array}$ & $\begin{array}{l}0.868 \\
{[<0.0001]}\end{array}$ & $\begin{array}{r}0.73366 \\
{[<0.0001]}\end{array}$ & & $\begin{array}{r}0.82598 \\
{[<0.0001]}\end{array}$ \\
\hline $\begin{array}{l}\text { Multiclass firm's lowest } \\
\text { monthly return (market adjusted) }\end{array}$ & $\begin{array}{r}0.73513 \\
{[<0.0001]}\end{array}$ & $\begin{array}{r}0.86968 \\
{[<0.0001]}\end{array}$ & $\begin{array}{c}0.8503 \\
{[<0.0001]}\end{array}$ & \\
\hline
\end{tabular}


indicate that the returns of different securities issued by the same firm are not identical, they (unsurprisingly) appear to be highly correlated.

\section{Abnormal Returns}

Next, I turn to an analysis of the abnormal returns for pseudo short-swing trades in my sample. Summary statistics of buy-first, sell-later (sell-first, buylater) pseudo short-swing insider trades are reported in Panel A (B) of Table 5. ${ }^{15}$ Consistent with the findings of Gompers et al. (2010), the multiclass firms in my sample are larger than the typical Compustat firm in the given year. In both samples (buy-first, sell later and sell-first, buy-later), the mean firm is in the sixth decile of firm size for the given year. Also consistent with the findings of Gompers et al., the multiclass firms in my sample have low valuations, relative to the broader sample of Compustat firms, as the median firm in my sample is in the third decile of Tobin's Q.

Table 6 reports abnormal returns for the pseudo short-swing insider trades of these sample firms. Panel A reports that the mean and median returns for pseudo short-swing insider trades of the buy-first, sell-later type are positive and statistically significant. The mean abnormal return over this interval is between approximately $11 \%$ and $14 \%$, depending on the abnormal return model, and the interval lasts on average approximately 105 days. That is, there are typically approximately 105 calendar days between the insider buying class A shares and selling

\section{TABLE 5}

Trade-Level Summary Statistics

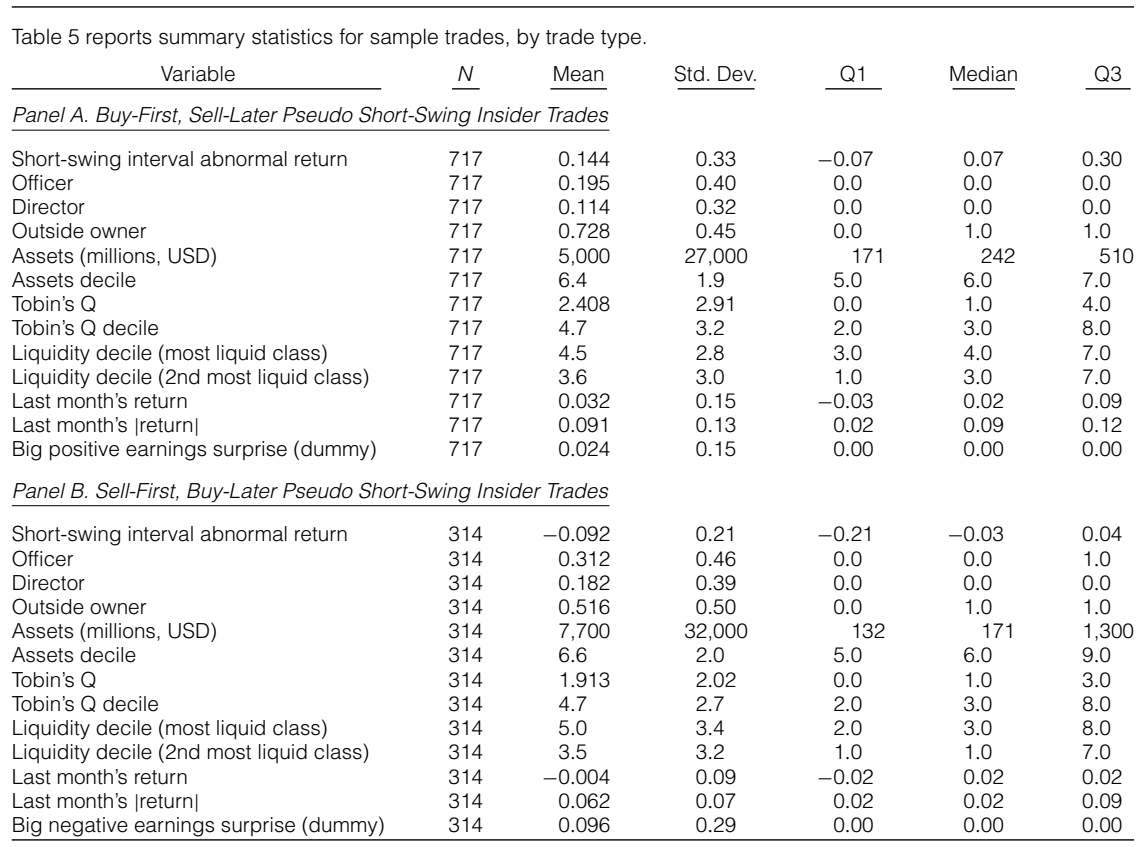

\footnotetext{
${ }^{15}$ Both samples lose a few trades from the Table 6 results because of data availability in Compustat.
} 
TABLE 6

Abnormal Returns to Pseudo Short-Swing Insider Trading

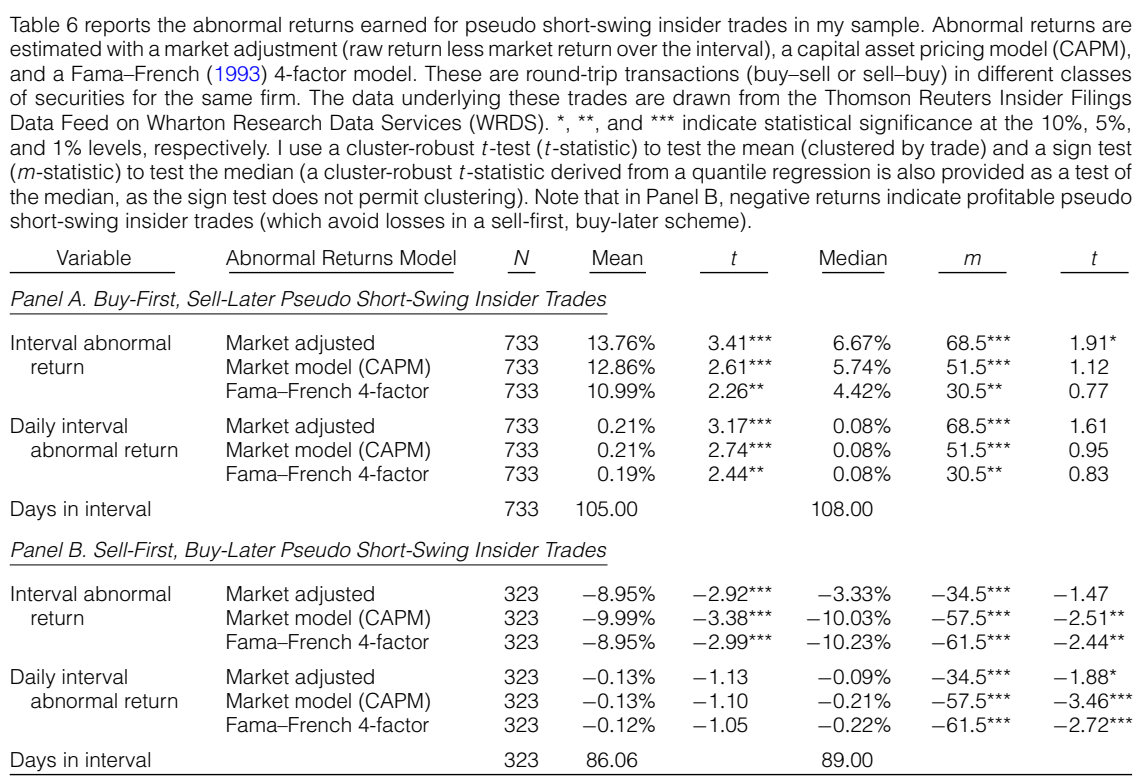

class B shares (of the same firm; see Figure 2 for a histogram of these intervals). Mean daily excess returns range from 19 to 21 basis points and are, as with the interval abnormal returns discussed earlier, statistically significant in $t$-tests clustered on trade (and in untabulated tests that cluster by firm or omit clustering altogether). Median abnormal returns are more modest (between $4 \%$ and $7 \%$ over the short-swing interval) and are statistically significant only in tests uncorrected for clustering. ${ }^{16}$

By comparison, Wang et al. (2012) observe that the inside purchases of U.S. CEOs and chief financial officers (CFOs) generate 12-month abnormal returns of approximately $4 \%$ on average. I find that pseudo short-swing insider purchases see returns that nearly triple that over a much shorter period (approximately 105 days).

Panel B of Table 6 describes a similar pattern of results for sell-first, buylater pseudo short-swing insider trades. The mean short-swing interval return (i.e., losses avoided between sale of class A and purchase of class B) is approximately $-9 \%(p<0.01)$ over an average (median) of $86(89)$ days. This is considerably larger than the annual abnormal return following typical insider sales by CEOs and CFOs (approximately -3\%; see Wang et al. (2012)). Median interval abnormal returns are also consistently negative in my sample

\footnotetext{
${ }^{16}$ I examine the statistical significance of the median abnormal returns via the sign test and a cluster robust $t$-test. The former ignores outliers and focuses instead on the ratio of positive to negative values (Davis (2007)), and the latter is clustered by trade. The sign test's usefulness in analyzing eventstudy abnormal returns (where outliers are common) is discussed by Corrado and Zivney (1992) and Boehmer, Masumeci, and Poulsen (1991).
} 
(between $-3 \%$ and $-10 \%$ ), as is the mean and median daily alpha (though mean daily alphas are not statistically significant). These values indicate insiders selling high, then turning around within a few months and buying low, avoiding considerable losses in the process.

This pattern and magnitude of returns paint a clear picture. When insiders can conduct short-swing trades in the United States, they earn substantial abnormal returns, beyond those typical of conventional insider trading (over similar horizons).

\section{Abnormal Profits}

The preceding tests examining abnormal returns offer evidence that insiders in multiclass firms exploit the loophole in Section 16(b) to execute profitable short-swing trades across different share classes. Cziraki and Gider (2016), however, show that the dollar value profitability of general insider trading is surprisingly modest. For example, they observe that median round-trip insider trading profits for insiders (over horizons longer than the required 6 months) are only $\$ 635$.

Table 7 reports similar abnormal dollar value profit figures for both buy-first, sell-later (Panel A) and sell-first, buy-later (Panel B) types of pseudo short-swing insider trades in my sample. A histogram of these dollar values is provided in Figure 3.

The abnormal dollar value profits for buy-first, sell-later pseudo short-swing insider trades are reported in Panel A of Table 7. Although the mean profitability of these trades is considerable (between $\$ 21,000$ and $\$ 37,000$, depending on the abnormal return model), the median short-swing trade in my sample sees only a few hundred dollars in total profitability.

Panel B of Table 7 reports the results for sell-first, buy-later pseudo shortswing insider trades. These results are considerably more modest. The median

\section{TABLE 7}

\section{Abnormal Profitability of Pseudo Short-Swing Insider Trading}

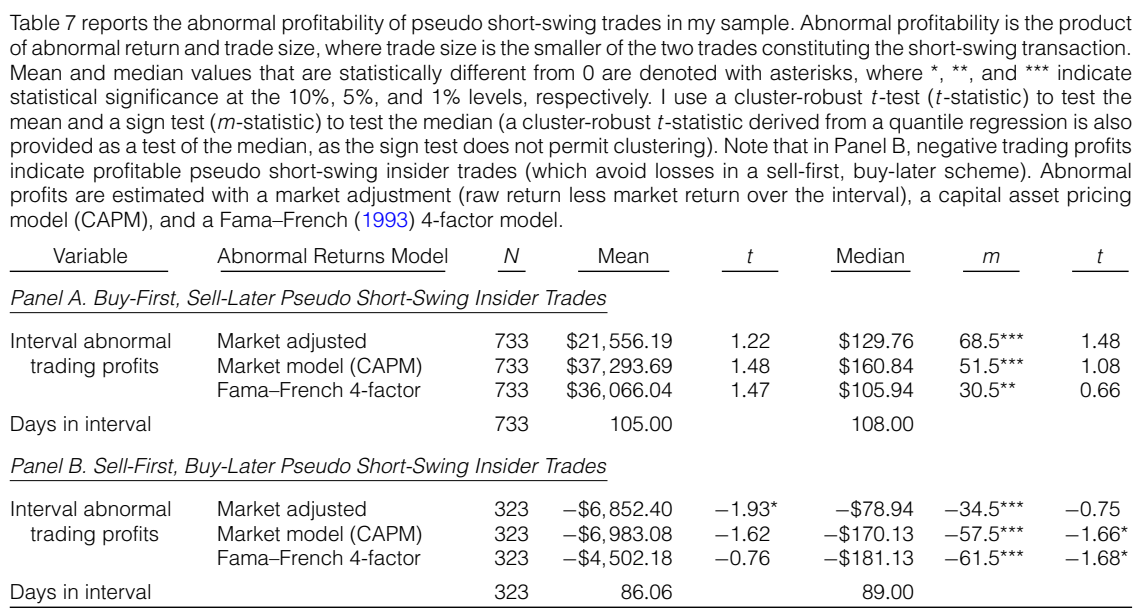


FIGURE 3

Short-Swing Trade Excess Profits by Opening Trade Direction

Figure 3 shows a histogram of the abnormal dollar profits for the pseudo short-swing transactions that constitute my sample. Abnormal dollar profits are calculated by multiplying excess returns (reverse coded for sell transactions) by trade size (smaller of the two trades).

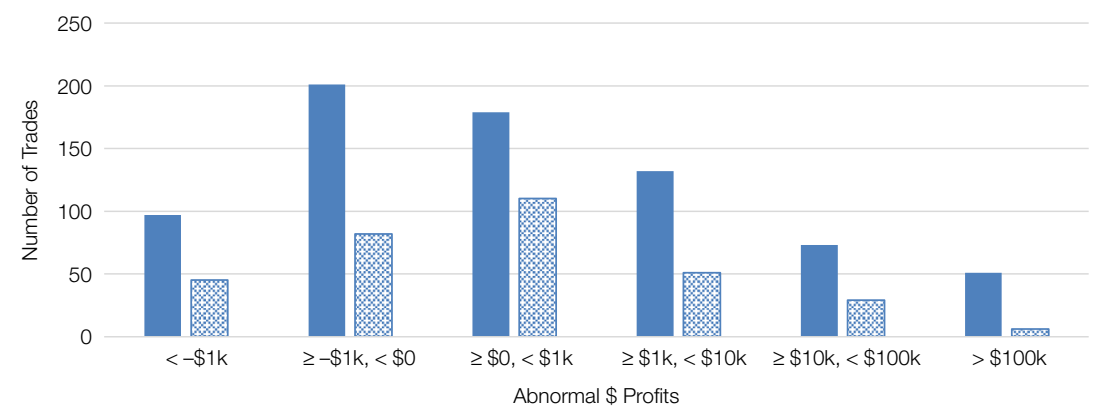

Buy First, Sell Later Sell First, Buy Later

values are consistently and significantly negative, indicating that these trades do avoid real dollar value losses but at negligible levels (\$180 per trade, at most).

Broadly, this analysis indicates that the dollar values of abnormal profits earned in pseudo short-swing insider trading in the United States are modest and in line with the broader (modest) profits of insider trading in general (where Cziraki and Gider (2016) find that the average U.S. insider earns approximately $\$ 12,000$ in abnormal profits per year). Policy interventions in this realm should be weighed against these small losses suffered by the investing public. However, given the difficulty in trading across multiple classes of stock, the dollar value losses identified here are likely a lower bound for losses should this type of trading be permitted within single classes of stock. ${ }^{17}$ Similarly, these profits being small at the median but large at the mean could indicate that Rule $10 \mathrm{~b} 5$ has some ability to restrict informed short-swing trading, as a minority of these trades appear to generate the type of trading losses necessary to spur 10b5 litigation. Also, this pattern of results could indicate multiple drivers of short-swing insider trading. Some of the traders are likely exploiting information advantages and the legal loophole at the center of this study, whereas others are likely trading for less nefarious reasons. Given the median trading profits involved, the data indicate that this latter group is larger.

\section{E. Trading Around Earnings Surprises}

Next, I examine whether insiders use pseudo short-swing insider trading to profit from earnings surprises. Trading before such announcements is widely understood to be both a legal and fiduciary impropriety (Ke et al. (2003)).

\footnotetext{
${ }^{17}$ This supposition is supported in untabulated analysis that reestimates the main results using only the most liquid share class. As expected, an information-based trading strategy in these more efficient markets yields higher abnormal returns (particularly in the sell-first, buy-later type of trades that avoid bad news).
} 
I examine how frequently large, beneficial earnings surprises occur within the pseudo short-swing intervals in my sample.

I define large earnings surprises as earnings announcements in the highest and lowest deciles of percentage difference from consensus analyst expectation scaled by price, per year, as in Hirshleifer, Lim, and Teoh (2009) and Dellavigna and Pollet (2009). ${ }^{18}$ I define beneficial surprises as positive surprises that occur between an opening buy and closing sell, in a buy-first, sell-later pseudo shortswing insider trade, and negative surprises that occur between an opening sell and closing buy, in a sell-first, buy-later pseudo short-swing insider trade. Note that beyond the conventional enforcement regime, most firms impose their own blackout restrictions on insider trading around earnings announcements that forbid transactions within a defined period, such as a month, around earnings releases (e.g., Jagolinzer et al. (2011), Bettis, Coles, and Lemmon (2000), and Roulstone (2003)). ${ }^{19}$

I observe that 17 of the 733 buy-first, sell-later pseudo short-swing insider trades in my sample bracket a big positive earnings surprise. These trades involve insiders ramping up their exposure to the firm on the open market before a big, positive earnings surprise and then unwinding their position after the (typically profitable) announcement. Similarly, 30 of the 323 sell-first, buy-later pseudo short-swing insider trades bracket a large negative earnings surprise $(p<0.001){ }^{20}$ In these cases, insiders unwind their position in the firm before the announcement of unexpectedly bad earnings news and then reinvest afterward via a different class of stock (in the same firm). In doing so, they can maintain their investment level and avoid the losses associated with the disclosure of poor earnings. It appears that the conventional investor protection framework can fail, even in these egregious instances, to restrain insiders from exploiting private information related to upcoming earnings news in short-swing transactions with outside investors.

\section{F. Predicting Cross-Sectional Abnormal Returns}

Next, I model the abnormal returns to these short-swing insider trades via ordinary least squares (OLS). This analysis is largely an exploratory effort to identify trading strategies or covariates underlying the large returns observed in Table 6.

Table 8 reports models estimating the abnormal return to pseudo shortswing insider trades as a function of insider, firm, and security characteristics.

\footnotetext{
${ }^{18}$ I draw quarterly earnings and analyst forecast data from Institutional Brokers' Estimate System (IBES).

${ }^{19}$ The Sarbanes-Oxley Act mandates that the blackout period extend at least 3 days before and 3 days after the earnings announcement (Banks (2010)).

${ }^{20}$ I determine whether these frequencies (e.g., 30 bad earnings surprise events occurring in a sample of 323 sell-first, buy-later pseudo short-swing insider trades) are statistically unusual via a Monte Carlo randomization method. To do so, I replace (1,000 times) the start date of every pseudo short-swing insider trade in my sample with the date of another insider trade in the same direction for the same firm during my sample period (and hold this position for the same length of time as the pseudo short-swing insider trade). I observe how often this random selection of directionally consistent insider trades held over the same horizon includes as many (or more) beneficial earnings surprises as the actual data. This test confirms that the frequency of beneficial earnings surprises is statistically significant (i.e., unexpectedly high) in the sell-first, buy-later sample (Monte Carlo $p$-value $<0.001$ ) but not in the buy-first, sell-later sample.
} 
TABLE 8

Regressions Predicting the Abnormal Returns to Pseudo Short-Swing Insider Trading

Table 8 reports the results of ordinary least squares (OLS) models that estimate the market-adjusted abnormal return of pseudo short-swing insider trades as a function of insider status, firm characteristics, security characteristics, and big earnings surprises. Models 1 and 2 ( 3 and 4 ) estimate abnormal returns to buy-first, sell-later (sell-first, buy-later) pseudo short-swing insider trades. Abnormal returns are estimated using a simple market-adjusted model, and returns to sell-first models are reverse coded so that positive coefficients map to higher returns (i.e., positive coefficients in models 3 and 4 indicate more losses avoided). $t$-statistics are in square brackets below the coefficients. ${ }^{*}$ and ${ }^{* \star *}$ indicate statistical significance at the $10 \%$ and $1 \%$ levels, respectively. Standard errors are clustered at the firm level.

Dependent Variable:

Abnormal Return of Pseudo Short-Swing Insider Trade

\begin{tabular}{|c|c|c|c|c|}
\hline \multirow{2}{*}{ Variable } & & & & \\
\hline & 1 & 2 & 3 & 4 \\
\hline Outside owner (dummy) & $\begin{array}{l}0.2407^{\star \star \star} \\
{[3.2068]}\end{array}$ & $\begin{array}{l}0.2585^{\star \star \star} \\
{[3.5241]}\end{array}$ & $\begin{array}{c}0.0134 \\
{[0.1755]}\end{array}$ & $\begin{array}{c}0.0593 \\
{[0.7652]}\end{array}$ \\
\hline Director (dummy) & $\begin{array}{c}0.0264 \\
{[0.3261]}\end{array}$ & $\begin{array}{c}0.0735 \\
{[1.0401]}\end{array}$ & $\begin{array}{c}0.0416 \\
{[0.7516]}\end{array}$ & $\begin{array}{c}0.1046^{\star} \\
{[1.9236]}\end{array}$ \\
\hline In(Trade Size) & $\begin{array}{c}-0.0101 \\
{[-0.7008]}\end{array}$ & $\begin{array}{c}-0.0147 \\
{[-1.0163]}\end{array}$ & $\begin{array}{r}-0.0183^{*} \\
{[-1.7572]}\end{array}$ & $\begin{array}{c}-0.0139 \\
{[-1.3723]}\end{array}$ \\
\hline In(Assets) & $\begin{array}{c}0.0753 \\
{[0.8481]}\end{array}$ & $\begin{array}{c}0.0803 \\
{[0.8975]}\end{array}$ & $\begin{array}{r}-0.0685^{*} \\
{[-1.7164]}\end{array}$ & $\begin{array}{c}-0.053 \\
{[-1.3420]}\end{array}$ \\
\hline Tobin's $Q$ & $\begin{array}{c}0.0264 \\
{[1.5906]}\end{array}$ & $\begin{array}{c}0.0348^{*} \\
{[1.8309]}\end{array}$ & $\begin{array}{l}-0.0484^{\text {}}{ }^{* \star *} \\
{[-3.7780]}\end{array}$ & $\begin{array}{l}-0.0444^{\star \star \star *} \\
{[-3.5143]}\end{array}$ \\
\hline Liquidity decile of most liquid class & $\begin{array}{c}-0.0516 \\
{[-1.3635]}\end{array}$ & $\begin{array}{l}-0.0614^{\star} \\
{[-1.8501]}\end{array}$ & $\begin{array}{c}0.0165 \\
{[0.8389]}\end{array}$ & $\begin{array}{c}-0.0038 \\
{[-0.1929]}\end{array}$ \\
\hline Liquidity decile of second most liquid class & $\begin{array}{c}0.0131 \\
{[0.7364]}\end{array}$ & $\begin{array}{c}0.0136 \\
{[0.6102]}\end{array}$ & $\begin{array}{l}0.046 \\
{[1.2845]}\end{array}$ & $\begin{array}{c}0.0503 \\
{[1.4434]}\end{array}$ \\
\hline Prior month's return & $\begin{array}{r}0.3562^{\star} \\
{[1.7460]}\end{array}$ & $\begin{array}{r}0.3420^{\star} \\
{[1.7880]}\end{array}$ & $\begin{array}{c}-0.4844 \\
{[-1.4381]}\end{array}$ & $\begin{array}{c}-0.2691 \\
{[-0.8372]}\end{array}$ \\
\hline Absolute value of prior month's return & $\begin{array}{c}0.3029 \\
{[0.5523]}\end{array}$ & $\begin{array}{c}0.3392 \\
{[0.6446]}\end{array}$ & $\begin{array}{c}-0.2327 \\
{[-0.3889]}\end{array}$ & $\begin{array}{c}-0.2601 \\
{[-0.4181]}\end{array}$ \\
\hline Big positive earnings surprise (dummy) & & $\begin{array}{l}0.3233^{\star \star *} \\
{[3.4885]}\end{array}$ & & \\
\hline Big negative earnings surprise (dummy) & & & & $\begin{array}{l}0.2301^{\star \star \star} \\
{[3.8183]}\end{array}$ \\
\hline Constant & $\begin{array}{c}-0.3294 \\
{[-0.6332]}\end{array}$ & $\begin{array}{c}-0.3317 \\
{[-0.6335]}\end{array}$ & $\begin{array}{c}0.5851^{*} \\
{[1.7205]}\end{array}$ & $\begin{array}{c}0.4588 \\
{[1.3873]}\end{array}$ \\
\hline Type of pseudo short-swing insider trade & Buy-first, se & & Sell-first, bu & \\
\hline $\begin{array}{l}\text { No. of obs. } \\
R^{2}\end{array}$ & $\begin{array}{r}717 \\
0.169\end{array}$ & $\begin{array}{r}717 \\
0.187\end{array}$ & $\begin{array}{r}314 \\
0.190\end{array}$ & $\begin{array}{r}314 \\
0.236\end{array}$ \\
\hline
\end{tabular}

Model 1 suggests that for buy-first, sell-later trades, transactions by outside owners (blockholders) earn higher abnormal returns than those of directors or officers (the excluded category), which is an unusual finding, relative to studies of more typical insider trading settings (e.g., Cziraki and Gider (2016)). An examination of the underlying data indicates that this effect is driven by intense trading by a small number of institutions. ${ }^{21}$

Model 2 of Table 8 includes an indicator for buy-first, sell-later trades that bracket a big positive earnings surprise. The indicator loads with a positive and significant coefficient, suggesting (intuitively) that trades that time the market around good news releases are considerably more profitable than other trades.

${ }^{21}$ Notably, Blum Capital and Scopia Management are involved in multiple pseudo short-swing trades in which the smaller trade exceeded \$500,000. Blum Capital executed such trades in Waddell $\&$ Reed (a publicly traded asset manager), and Scopia Management traded in Central Garden \& Pet (a supplier of lawn and pet supplies). These trades generated significant excess returns at both the mean $(16 \%)$ and median $(20 \%)$. 
I estimate similar regressions in models 3 and 4 of Table 8 using sell-first, buy-later trades (the dependent variable in these models is reverse coded so positive coefficients translate to better returns for investors). The results of both models indicate that insiders in firms with low valuation multiples, as measured by Tobin's Q, earn better returns in sell-first transactions (i.e., avoid more losses). Model 4 incorporates an indicator for sell-first, buy-later trades that bracket a big negative earnings surprise, and as previously, this indicator is statistically significant $(p<0.01)$ in the expected direction. Unsurprisingly, trades that involve selling ahead of bad earnings news and then buying afterward lead to insiders avoiding considerable losses. This pattern of returns and its frequency indicates that at least some portion of the pseudo short-swing insider trades I observe are driven by insiders' foreknowledge of unexpected firm performance. ${ }^{22}$

\section{Extended Analyses}

In this section, I conduct a series of additional tests to further investigate i) the ability of insiders to profit from pseudo short-swing insider trading and ii) the type of firms involved in this sample.

\section{A. Returns Following Closing Trade}

Although the goal of this study is to determine whether the U.S. investor protection regime absent Section 16(b) is sufficient to protect U.S. investors from exploitative short-swing insider trading, I also investigate whether a profitable trading rule can take advantage of the well-informed insiders conducting trades in my sample. This is problematic, as the pseudo short-swing insider trades I examine are not identifiable ex ante, as discussed earlier. That is, of my possible sample of opening trades (all insider trades), the only ones that qualify as pseudo short-swing insider trades are those in which I observe the same insider trading in a different class in a different direction in the future (within 6 months). Once this has occurred, the short-swing interval is, by definition, already over, as it ended with the latter trade.

However, that latter trade likely occurs because an insider is trying to increase (via a purchase) or decrease (via a sale) his or her exposure to a firm's upcoming performance. This upcoming performance may be extreme, as well as unexpected, given that, before this closing trade, the insider was trading in the opposite direction. For example, if the CEO of firm X buys class A stock on Jan. 1, one likely explanation for a sale of class B stock on Mar. 1 would be that he or she has some new information that does not bode well for the position taken in the original trade (i.e., purchase of class A shares on Jan. 1).

These closing trades (e.g., the Mar. 1 sale of class B shares) are perfectly (and contemporaneously) identifiable as the closing trade in a pseudo short-swing insider trade (as one could match the CEO's Mar. 1 sale to the Jan. 1 buy), and I examine whether a portfolio mimicking such transactions earns abnormal returns going forward. This sample is smaller than that of all pseudo short-swing

\footnotetext{
${ }^{22}$ This is the type of insider trading that the U.S. Congress sought to forbid when framing Section 16(b) (e.g., O’Connor (1989), Fried (1997), and Jacobs (1987)).
} 
insider trades, as sometimes multiple opening pseudo short-swing insider trades are matched to a single closing trade, as would occur if an insider bought class A shares on Jan. 1 and Feb. 1 but sold class B shares on Mar. 1.

The returns to transactions of this type are reported in Table 9. I report abnormal returns over 1 - and 3-month horizons of trades that mimic the closing transaction in the pseudo short-swing insider trades in my sample.

Panel A of Table 9 reports the abnormal returns to mimicking the insider buys that follow within 6 months of the same insider's sale in a different class of stock for the same firm. The 1-month returns are not significant, and over the 3-month horizon these closing buys outperform the market by a statistically significant margin only in one of three models (market adjusted, where mean returns $=4.1 \%$, $p<0.05)$.

Panel B of Table 9 reports the abnormal returns to mimicking the insider sales that follow within 6 months of the same insider's buy in a different class of stock for the same firm. The mean and median excess returns to these trades over the 1-month window are approximately $-3 \%$, suggesting that insiders in these situations sell stock before substantial price declines. These returns are statistically significant in two of three models. No notable results emerge from the analysis of abnormal returns over the 3-month window following these closing sells.

This exploratory analysis is probably of negligible use to the investing community, given the small sample size (fewer than 400 trades over 18 years), but it does illuminate the types of returns earned in and around pseudo short-swing insider trades. For the typical buy-first, sell-later insider trade, an insider beats the market with his purchase by approximately $13 \%$ over 105 days, after which that

\section{TABLE 9}

Abnormal Returns to Mimicking the Closing Trade in Pseudo Short-Swing Insider Trading

Table 9 reports the abnormal returns to mimicking the closing (contemporaneously identifiable) pseudo short-swing insider trade transactions (the sell that comes after a buy in a different class and vice versa). Abnormal returns are estimated with a market adjustment (raw return less market return over the interval), a capital asset pricing model (CAPM), and a Fama-French (1993) 4-factor model. The data underlying these trades are drawn from the Thomson Reuters Insider Filings Data Feed on Wharton Research Data Services (WRDS). ${ }^{*},{ }^{* *}$, and ${ }^{* * *}$ indicate statistical significance at the $10 \%$, $5 \%$, and $1 \%$ levels, respectively. I use a $t$-test ( $t$-statistic) to test the mean and a sign test ( $m$-statistic) to test the median. Note that in Panel B, negative returns indicate profitable pseudo short-swing insider trades (which avoid losses with a sell).

\begin{tabular}{|c|c|c|c|c|c|c|c|}
\hline Variable & Abnormal Returns Model & $N$ & Mean & $t$ & Median & $m$ & $t$ \\
\hline Panel A. Sell-First, B & ater Pseudo Short-Swing & $\operatorname{lor}$ & & & & & \\
\hline $\begin{array}{l}\text { Mimic insider buys, } \\
\text { hold for } 1 \text { month } \\
\text { (abnormal return) }\end{array}$ & $\begin{array}{l}\text { Market adjusted } \\
\text { Market model (CAPM) } \\
\text { Fama-French 4-factor }\end{array}$ & $\begin{array}{l}209 \\
209 \\
209\end{array}$ & $\begin{array}{r}0.53 \% \\
-0.18 \% \\
0.23 \%\end{array}$ & $\begin{array}{r}0.46 \\
-0.10 \\
0.12\end{array}$ & $\begin{array}{r}0.02 \% \\
-1.03 \% \\
-0.83 \%\end{array}$ & $\begin{array}{r}1.5 \\
-11.5 \\
-6.5\end{array}$ & $\begin{array}{r}0.02 \\
-0.46 \\
-0.33\end{array}$ \\
\hline $\begin{array}{r}\text { Mimic insider buys, } \\
\text { hold for } 3 \text { months } \\
\text { (abnormal return) }\end{array}$ & $\begin{array}{l}\text { Market adjusted } \\
\text { Market model (CAPM) } \\
\text { Fama-French 4-factor }\end{array}$ & $\begin{array}{l}209 \\
209 \\
209\end{array}$ & $\begin{array}{l}4.11 \% \\
2.01 \% \\
3.36 \%\end{array}$ & $\begin{array}{l}2.22^{\star \star} \\
0.67 \\
0.98\end{array}$ & $\begin{array}{l}1.88 \% \\
2.10 \% \\
0.48 \%\end{array}$ & $\begin{array}{c}14.5^{*} \\
7.5 \\
8.5\end{array}$ & $\begin{array}{l}1.91^{\star} \\
0.77 \\
0.12\end{array}$ \\
\hline Panel B. Buy-First, S & Later Pseudo Short-Swing I & El 116 & & & & & \\
\hline $\begin{array}{l}\text { Mimic insider sells, } \\
\text { hold for } 1 \text { month } \\
\text { (abnormal return) }\end{array}$ & $\begin{array}{l}\text { Market adjusted } \\
\text { Market model (CAPM) } \\
\text { Fama-French 4-factor }\end{array}$ & $\begin{array}{l}166 \\
166 \\
166\end{array}$ & $\begin{array}{l}-1.70 \% \\
-3.02 \% \\
-3.23 \%\end{array}$ & $\begin{array}{l}-0.88 \\
-2.08^{\star \star} \\
-2.25^{\star \star}\end{array}$ & $\begin{array}{l}-2.87 \% \\
-2.89 \% \\
-3.09 \%\end{array}$ & $\begin{array}{c}-10 \\
-17^{\star \star} \\
-20^{\star \star \star}\end{array}$ & $\begin{array}{l}-1.78^{\star} \\
-2.04^{\star} \\
-2.74^{\star \star \star}\end{array}$ \\
\hline $\begin{array}{l}\text { Mimic insider sells, } \\
\text { hold for } 3 \text { months } \\
\text { (abnormal return) }\end{array}$ & $\begin{array}{l}\text { Market adjusted } \\
\text { Market model (CAPM) } \\
\text { Fama-French 4-factor }\end{array}$ & $\begin{array}{l}166 \\
166 \\
166\end{array}$ & $\begin{array}{l}-0.36 \% \\
-2.84 \% \\
-2.82 \%\end{array}$ & $\begin{array}{l}-0.10 \\
-1.00 \\
-0.95\end{array}$ & $\begin{array}{l}-1.23 \% \\
-1.97 \% \\
-0.11 \%\end{array}$ & $\begin{array}{l}-11 \\
-4 \\
-1\end{array}$ & $\begin{array}{l}-0.38 \\
-0.61 \\
-0.08\end{array}$ \\
\hline
\end{tabular}


insider sells in another class of stock in the same firm that goes on to underperform (beat) the market by approximately $3 \%$ over the following month. Analogously, the typical sell-first, buy-later pseudo short-swing insider trade involves an insider selling one class of stock, which goes on to underperform the market by approximately $9 \%$ over the next 86 days (a period that is considerably more likely than random to include a large, negative earnings surprise), followed with a buy in another class of stock in the same firm that subsequently outperforms the market by approximately $4 \%$ over the next quarter. In sum, both legs of these trades appear to be well timed (though the statistical support for this timing is weak in some cases, perhaps because of small sample sizes).

To benchmark these returns, Cohen et al. (2012) find that the opportunistic (unplanned) buys of insiders earn a monthly alpha of approximately $1.5 \%$, which is comparable to the monthly alpha generated over the 3-month window following insider buys in my sample that conclude pseudo short-swing insider trading. Opportunistic sales studied by Cohen et al. underperform the market by approximately $0.19 \%$ per month, whereas sales that close pseudo short-swing insider trades go on to underperform the market by approximately $3 \%$ over the following month. These results comport with the transactions I observe being unplanned, given that they are reversing a position recently taken by the insider (within the last 6 months). ${ }^{23}$ In terms of trade size, the closing (opening) trade tends to be larger for buy-first (sell-first) short-swing trades (see Table 1), likely because divesting does not require the insider to accumulate a large quantity of cash beforehand.

\section{B. Selection Model}

Next, I examine the type of firms that, in general, have multiple classes of traded stock. This is important primarily in determining whether my results generalize to the broader population of U.S. firms. Table 10 reports the univariate differences between firms with multiple classes of stock and those with a single class of stock. Multiclass firms are larger, more levered, and have lower valuations, but the primary difference seems to be in firm age. Firms that first listed before the 1990s are much more likely to have multiple classes of stock. Paralleling this trend, multiclass firms are more likely to be involved in manufacturing basic goods (nondurable consumer goods) and less likely to operate in the financial or healthcare sectors.

Table 11 reports a logit model estimating whether a firm has more than one class of listed stock at its first appearance on the CRSP and Compustat tapes during my sample period (1996-2013). As in Table 10 (and Gompers et al. (2010)), firms with lower Tobin's Q (market/book) are more likely to have multiple classes of traded stock. However, this effect is small relative to the effect of age. For example, with other controls set at the median, shifting Tobin's $Q$ from the first to third quartile (1.3 to 4.1$)$ decreases the likelihood of having multiple classes

\footnotetext{
${ }^{23}$ For comparison, I contrast the Fama-French (1993) 4-factor alphas from Table 4 of Cohen et al. (2012) to the results of the same model applied to my data.
} 
TABLE 10

Differences between Single-Class and Multiclass Firms: Univariate Tests

\begin{tabular}{|c|c|c|c|}
\hline & Mea & & \\
\hline & Single Class Firms & Multiclass Firms & $t$ \\
\hline Sample Size & 12,882 & 200 & \\
\hline $\begin{array}{l}\text { Firm Characteristics } \\
\text { Assets } \\
\text { Bid-ask spread (\%) } \\
\text { Tobin's } Q \\
\text { Leverage }\end{array}$ & $\begin{array}{r}1,293.23 \\
1.04 \\
3.62 \\
0.19\end{array}$ & $\begin{array}{r}3,899.90 \\
1.04 \\
2.45 \\
0.27\end{array}$ & 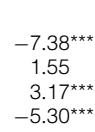 \\
\hline $\begin{array}{l}\text { Primary Industry } \\
\text { Consumer nondurables (food, tobacco, toys, etc.) } \\
\text { Consumer durables (cars, appliances, furniture, etc.) } \\
\text { Manufacturing (machinery, trucks, planes, etc.) } \\
\text { Energy (oil, gas, coal, etc.) } \\
\text { Chemicals } \\
\text { Business equip. (computers, printers, software, etc.) } \\
\text { Telecommunications (phones, TV channels, etc.) } \\
\text { Utilities } \\
\text { Shopping (retail, wholesale) } \\
\text { Healthcare, medical equipment, pharmaceuticals } \\
\text { Finance } \\
\text { Other industry }\end{array}$ & $\begin{array}{l}0.04 \\
0.02 \\
0.08 \\
0.04 \\
0.02 \\
0.18 \\
0.04 \\
0.02 \\
0.09 \\
0.10 \\
0.21 \\
0.16\end{array}$ & $\begin{array}{l}0.09 \\
0.01 \\
0.11 \\
0.06 \\
0.01 \\
0.12 \\
0.16 \\
0.01 \\
0.11 \\
0.04 \\
0.11 \\
0.17\end{array}$ & $\begin{array}{l}-4.26^{\star \star \star} \\
0.62 \\
-1.40 \\
-1.31 \\
0.77 \\
2.30^{\star \star} \\
-8.52^{\star \star \star} \\
0.94 \\
-0.81 \\
2.41^{\star \star} \\
3.76^{\star \star \star} \\
-0.24\end{array}$ \\
\hline $\begin{array}{l}\text { Decade of IPO } \\
\text { IPO in } 1920 \text { s } \\
\text { IPO in } 1930 \text { s } \\
\text { IPO in } 1940 \text { s } \\
\text { IPO in } 1950 \text { s } \\
\text { IPO in } 1960 \text { s } \\
\text { IPO in } 1970 \text { s } \\
\text { IPO in } 1980 \text { s } \\
\text { IPO in } 1990 \text { s } \\
\text { IPO in } 2000 \text { s } \\
\text { IPO in } 2010 \text { s }\end{array}$ & $\begin{array}{l}0.01 \\
0.01 \\
0.01 \\
0.01 \\
0.03 \\
0.07 \\
0.17 \\
0.47 \\
0.20 \\
0.03\end{array}$ & $\begin{array}{l}0.03 \\
0.01 \\
0.02 \\
0.01 \\
0.11 \\
0.19 \\
0.20 \\
0.28 \\
0.14 \\
0.01 \\
\end{array}$ & $\begin{array}{l}-2.66^{\star \star \star} \\
-0.58 \\
-2.17^{\star \star} \\
-0.84 \\
-6.70^{\star \star \star} \\
-6.14^{\star \star \star} \\
-1.16 \\
5.28^{\star \star \star} \\
2.09^{\star \star} \\
1.28\end{array}$ \\
\hline
\end{tabular}

of listed stock from only $2.4 \%$ to $2.1 \%$. By comparison, shifting the decade of IPO from the 1990s to the 1960s increases the probability that a firm has multiple classes of listed stock (in the 1990s and 2000s) from approximately $2.3 \%$ to approximately $7.3 \%$.

Table 11 should help reduce concerns about whether my results would generalize to single-class firms in the absence of Section 16(b). Although multiclass firms tend to have lower valuation multiples and larger balance sheets than singleclass firms, the biggest differences (and perhaps what is driving the results in size and Tobin's Q) are in firm age. Firms that underwent initial public offerings (IPOs) in the 1990s and later did so in markets much more concerned with shareholder rights and corporate governance (Shleifer and Vishny (1997), Holmstrom and Kaplan (2001)), both of which are strengthened by single-class ownership structures (e.g., Gompers et al. (2010)). This indicates that although the multiclass firms I analyze may not be directly comparable to the broader sample of public U.S. firms on all fronts, differences are primarily in age, which is perhaps not a large concern with regard to generalizability (i.e., the types of firms in my sample have lower valuation multiples and larger balance sheets than the typical Compustat firm, but these characteristics are not economically meaningful predictors of having multiple classes of traded stock). 


\begin{tabular}{|c|c|c|}
\hline & \multicolumn{2}{|c|}{$\begin{array}{l}\text { Logit Model: DV = } 1 \text { If Firm Has } \\
\text { Multiple Classes of Listed Stock }\end{array}$} \\
\hline & Coefficient & $z$ \\
\hline $\begin{array}{l}\text { Firm Characteristics } \\
\text { Assets } \\
\text { Bid-ask spread (\%) } \\
\text { Tobin's Q } \\
\text { Leverage }\end{array}$ & $\begin{array}{r}0.01 \\
-1.90 \\
-0.05 \\
0.79\end{array}$ & $\begin{array}{l}4.34^{\star \star \star} \\
-1.16 \\
-2.44^{\star \star} \\
2.29^{\star \star}\end{array}$ \\
\hline $\begin{array}{l}\text { Primary Industry (Excluded Industry = Consumer Non } \\
\text { Consumer durables (cars, appliances, furniture, etc.) } \\
\text { Manufacturing (machinery, trucks, planes, etc.) } \\
\text { Energy (oil, gas, coal, etc.) } \\
\text { Chemicals } \\
\text { Business equip. (computers, printers, software, etc.) } \\
\text { Telecommunications (phones, TV channels, etc.) } \\
\text { Utilities } \\
\text { Shopping (retail, wholesale) } \\
\text { Healthcare, medical equipment, pharmaceuticals } \\
\text { Finance } \\
\text { Other industry }\end{array}$ & $\begin{array}{r}-1.42 \\
-0.79 \\
-0.51 \\
-1.58 \\
-0.97 \\
0.59 \\
-2.23 \\
-0.72 \\
-1.16 \\
-1.73 \\
-0.58\end{array}$ & $\begin{array}{l}-2.24^{\star \star} \\
-2.42^{\star \star} \\
-1.34 \\
-2.10^{\star \star} \\
-3.02^{\star \star \star} \\
1.86^{\star} \\
-2.96^{\star \star \star} \\
-2.16^{\star \star} \\
-2.81^{\star \star \star} \\
-5.07^{\star \star \star} \\
-1.95^{\star}\end{array}$ \\
\hline $\begin{array}{l}\text { Decade of IPO (Excluded Period }=I P O<1980 \text { s) } \\
\text { IPO in } 1980 \text { s or } 1990 \text { s } \\
\text { IPO in } 2000 \text { s or } 2010 \text { s } \\
\text { Constant }\end{array}$ & $\begin{array}{l}-1.18 \\
-1.50 \\
-0.61\end{array}$ & $\begin{array}{l}-6.64^{\star \star \star} \\
-6.20^{\star \star \star} \\
-0.35\end{array}$ \\
\hline $\begin{array}{l}\text { No. of obs. } \\
\text { Pseudo- } R^{2}\end{array}$ & $\begin{array}{c}13,082 \\
0.09\end{array}$ & \\
\hline
\end{tabular}

\section{Conclusion}

What protects outside investors from insider trading in the United States? This is a difficult question, in that the regulatory system entails multiple protections working together, and attributing credit to any one or a combination is complicated. The consensus of research is that the current system of insider trading protections involves a well-provisioned SEC, along with an efficient class-action system, enforcing a principles-based prohibition on insiders trading on private information (Rule 10b5), all within a common law legal environment.

However, an element of this regulatory framework that receives less attention is the bright-line prohibition on short-swing insider trading, which perhaps lightens the burden of investor protection borne by the remainder of the regulatory framework. I examine whether this prohibition is necessary to protect outside investors in the United States or whether the remainder of the regulatory regime is sufficient in its absence. My findings suggest that when the short-swing insider trading prohibition fails to bind, the remaining investor protection system does not provide adequate protection to outside investors in some cases, which results in typical short-swing insider trades earning abnormal returns of approximately $10 \%$ over a 3 -month period.

For securities regulators in the United States and abroad, this result generates two insights. First, generously funded, well-staffed regulators and accessible class-action systems can fail to protect outside investors from short-horizon 
insider trading, even in a sound legal system. These elements are likely necessary to protect outside investors from such insider trading but are not enough. ${ }^{24} \mathrm{Sec}-$ ond, the information advantages of U.S. insiders are especially valuable over short windows. The silver lining is that both of these issues can be remedied by a simple, bright-line restriction on insiders trading both ways in their firms' stocks over short horizons. This previously underappreciated element of securities regulation appears to play a substantial role in restraining insider profits and protecting outside investors.

In a broader sense, this result also demonstrates that the regulatory systems in place in Western-style markets are complex and interdependent. Individual elements, such as having a well-funded securities regulator or strong laws, may be beneficial but only in a framework incorporating other essential elements. Unraveling a single strand of this framework, even one that receives relatively little attention or credit, can weaken the securities regulatory system and place outside investors at risk.

Finally, this result speaks to the ongoing debate in the securities law literature over whether Section 16(b) benefits outside investors in securities markets. One does not have to look hard to find critics who claim that the remaining system would be capable of protecting outside investors from short-swing insider trading if Section 16(b) were repealed (e.g., O'Connor (1989), Dessent (1999), Manne (2008), Taylor (1997), Munter (1966), Lowenfels (1968), Ishizumi (1978), and Jennings, Marsh, and Coffee (1992)). My findings illustrate that this is not the case and that the bright-line rule, though perhaps a "dumb" catchall, clearly plays a valuable role in protecting outside investors in U.S. securities markets.

\section{Appendix. Restricted Samples}

In this Appendix, I remove all duplicate trades from the data. When multiple opening transactions are matched to a single closing transaction, only the pair of trades (open and close) with the shortest intervening interval are retained. Multiple closing transactions matched to a single opening trade are similarly treated.

This yields a sample without any repeated observations influencing the tests. Furthermore, removing longer windows and repeated trades in this analysis biases abnormal returns toward 0 , as particularly profitable insider trading opportunities tend to be traded over longer windows and repeatedly.

Although the buy-first, sell-later trades (Table A1) see no notable excess returns, the sell-first, buy-later pseudo short-swing insider trades (Table A2) earn excess returns (avoid abnormal losses) on the order of $-5 \%(p<0.05)$ over a window of only 70 days. This provides evidence generally consistent with that reported in the preceding (less conservative) analysis confirming that U.S. insiders unburdened with a bright-line rule restricting short-horizon insider trading can harness information advantages and execute exploitative trades with outside investors.

\footnotetext{
${ }^{24}$ That is, Rule $10 \mathrm{~b} 5$ is likely a crucially important part of the insider trading regime. However, it is not sufficient on its own to dissuade all instances of insiders trading on private information over short horizons.
} 
TABLE A1

Buy-First, Sell-Later Trades

Table A1 reports the abnormal returns earned for pseudo short-swing insider trades in my sample. I remove all duplicate trades from the data in this analysis. When multiple opening transactions are matched to a single closing transaction, only the pair of trades (open and close) with the shortest intervening interval are retained. Multiple closing transactions matched to a single opening trade are similarly treated. Abnormal returns are estimated with a market adjustment (raw return less market return over the interval), a capital asset pricing model (CAPM), and a Fama-French (1993) 4-factor model. These are round-trip transactions (buy-sell) in different classes of securities for the same firm. The data underlying these trades are drawn from the Thomson Reuters Insider Filings Data Feed on Wharton Research Data Services (WRDS). ${ }^{*},{ }^{\star *}$, and ${ }^{* * *}$ indicate statistical significance at the $10 \%, 5 \%$, and $1 \%$ levels, respectively. I use a cluster-robust $t$-test ( $t$-statistic) to test the mean (clustered by trade) and a sign test ( $m$-statistic) to test the median.

\begin{tabular}{|c|c|c|c|c|c|c|}
\hline Variable & Abnormal Returns Model & No. of Obs. & Mean & $t$ & Median & $m$ \\
\hline Interval abnormal return & $\begin{array}{l}\text { Market adjusted } \\
\text { Market model (CAPM) } \\
\text { Fama-French 4-factor }\end{array}$ & $\begin{array}{l}74 \\
74 \\
74\end{array}$ & $\begin{array}{r}1.91 \% \\
-1.68 \% \\
-0.94 \%\end{array}$ & $\begin{array}{r}1.04 \\
-0.46 \\
-0.28\end{array}$ & $\begin{array}{r}-0.53 \% \\
0.03 \% \\
-0.02 \%\end{array}$ & $\begin{array}{r}-1.00 \\
0.00 \\
0.00\end{array}$ \\
\hline Daily interval abnormal return & $\begin{array}{l}\text { Market adjusted } \\
\text { Market model (CAPM) } \\
\text { Fama-French 4-factor }\end{array}$ & $\begin{array}{l}74 \\
74 \\
74\end{array}$ & $\begin{array}{l}0.10 \% \\
0.09 \% \\
0.10 \%\end{array}$ & $\begin{array}{l}0.75 \\
0.6 \\
0.68\end{array}$ & $\begin{array}{l}-0.026 \% \\
-0.003 \% \\
-0.005 \%\end{array}$ & $\begin{array}{l}0.46 \\
0.00 \\
0.00\end{array}$ \\
\hline Days in interval & & 74 & 72.09 & & 69.00 & \\
\hline
\end{tabular}

TABLE A2

Sell-First, Buy-Later Trades

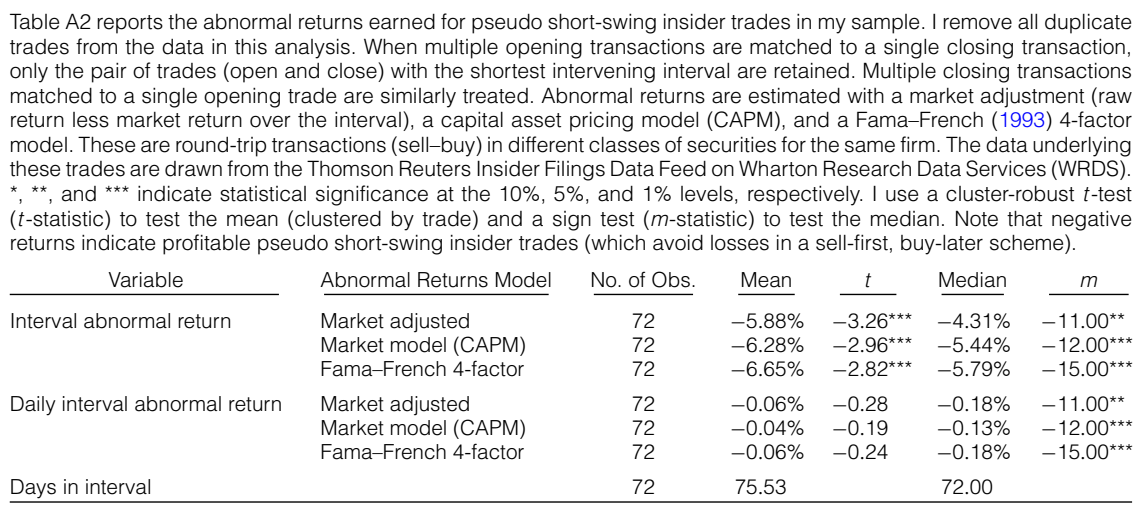

\section{References}

Agrawal, A., and J. F. Jaffe. "Does Section 16b Deter Insider Trading by Target Managers?" Journal of Financial Economics, 39 (1995), 295-319.

Amel-Zadeh, A.; J. Faasse; and J. Lotz. "Are All Insider Sales Created Equal? Evidence from Form 4 Footnote Disclosures." Working Paper, Oxford University (2018).

Amoako-Adu, B., and B. F. Smith. "Dual Class Firms: Capitalization, Ownership Structure and Recapitalization Back into Single Class." Journal of Banking \& Finance, 25 (2001), 1083-1111.

Anthony, L. "Section 16 Insider Reporting and Liability for Short-Swing Trading." White Paper, Legal \& Compliance LLC (2014).

Ausubel, L. M. "Insider Trading in a Rational Expectations Economy." American Economic Review, 80 (1990), 1022-1041.

Banks, T. L. Corporate Legal Compliance Handbook. 2nd ed. New York, NY: Aspen Publishers Online (2010).

Bettis, J. C.; J. L. Coles; and M. L. Lemmon. "Corporate Policies Restricting Trading by Insiders." Journal of Financial Economics, 57 (2000), 191-220.

Bhattacharya, U., and H. Daouk. "The World Price of Insider Trading." Journal of Finance, 57 (2002), 75-108.

Black, B. S. "The Legal and Institutional Preconditions for Strong Securities Markets." UCLA Law Review, 48 (2001), 781-855. 
Boehmer, E.; J. Masumeci; and A. B. Poulsen. "Event-Study Methodology under Conditions of EventInduced Variance.” Journal of Financial Economics, 30 (1991), 253-272.

Brochet, F. "Information Content of Insider Trades Before and After the Sarbanes-Oxley Act." Accounting Review, 85 (2010), 419-446.

Bucklo, E. E. "The Supreme Court Attempts to Define Scienter Under Rule 10b-5: Ernst \& Ernst v. Hochfelder." Stanford Law Review, 29 (1977), 213-240.

Bushman, R. M.; J. D. Piotroski; and A. J. Smith. "Insider Trading Restrictions and Analysts' Incentives to Follow Firms." Journal of Finance, 60 (2005), 35-66.

Cao, C.; L. C. Field; and G. Hanka. "Does Insider Trading Impair Market Liquidity? Evidence from IPO Lockup Expirations.” Journal of Financial and Quantitative Analysis, 39 (2004), 25-46.

Carangelo, R. F.; P. A. Ferrillo; D. J. Schwartz; and M. D. Altemeier. The 10b-5 Guide: A Survey of 2010-2011 Securities Fraud Litigation. New York, NY: Weil, Gotshal \& Manges LLP (2012).

Carhart, M. M. "On Persistence in Mutual Fund Performance.” Journal of Finance, 52 (1997), 57-82.

Chen, Z.; Y. Guan; and B. Ke. "The Short-Swing Rule and Insider Trading." Working Paper, City University of Hong Kong and Nanyang Technological University (2014).

Cheng, C.; H. Huang; Y. Li; and G. Lobo. "Institutional monitoring through shareholder litigation." Journal of Financial Economics, 95 (2010), 356-383.

Christensen, H. B.; L. Hail; and C. Leuz. "Capital-Market Effects of Securities Regulation: Prior Conditions, Implementation, and Enforcement.” Review of Financial Studies, 29 (2016), 2885-2924.

Chung, K. H., and C. Charoenwong. "Insider Trading and the Bid-Ask Spread.” Financial Review, 33 (1998), 1-20.

Coffee, J. C. "Reforming the Securities Class Action: An Essay on Deterrence and Its Implementation." Columbia Law Review, 106 (2006), 1534-1586.

Cohen, L.; C. Malloy; and L. Pomorski. "Decoding Inside Information.” Journal of Finance, 67 (2012), 1009-1043.

Comolli, R., and S. Starykh. Recent Trends in Securities Class Action Litigation: 2014 Full-Year Review. New York, NY: NERA Economic Consulting (2015).

Cornell, B., and E. R. Sirri. "The Reaction of Investors and Stock Prices to Insider Trading." Journal of Finance, 47 (1992), 1031-1059.

Corrado, C. J., and T. L. Zivney. "The Specification and Power of the Sign Test in Event Study Hypothesis Tests Using Daily Stock Returns." Journal of Financial and Quantitative Analysis, 27 (1992), 465-478.

Cziraki, P., and J. Gider. "Perks or Peanuts? The Dollar Profits to Insider Trading." Working Paper, University of Toronto and University of Bonn (2016).

Davis, J. B. Statistics Using SAS Enterprise Guide. Cary, NC: SAS Institute (2007).

DeAngelo, H., and L. DeAngelo. "Managerial Ownership of Voting Rights: A Study of Public Corporations with Dual Classes of Common Stock." Journal of Financial Economics, 14 (1985), 33-69.

Dellavigna, S., and J. M. Pollet. "Investor Inattention and Friday Earnings Announcements." Journal of Finance, 64 (2009), 709-749.

DeMarzo, P. M.; M. J. Fishman; and K. M. Hagerty. "The Optimal Enforcement of Insider Trading Regulations." Journal of Political Economy, 106 (1998), 602-632.

Dessent, M. H. "Weapons to Fight Insider Trading in the 21st Century: A Call for the Repeal of Section 16(B)." Akron Law Review, 33 (1999), 481-522.

Easterbrook, F. H., and D. R. Fischel. The Economic Structure of Corporate Law. Cambridge, MA: Harvard University Press (1991).

Fama, E. F., and K. R. French. "Common Risk Factors in the Returns on Stocks and Bonds." Journal of Financial Economics, 33 (1993), 3-56.

Fernandes, N., and M. A. Ferreira. "Insider Trading Laws and Stock Price Informativeness.” Review of Financial Studies, 22 (2009), 1845-1887.

Ferrell, A., and A. Saha. "Forward-Casting 10b-5 Damages: A Comparison to Other Methods." Journal of Corporation Law, 37 (2011), 365-386.

Field, L.; M. Lowry; and S. Shu. "Does Disclosure Deter or Trigger Litigation?” Journal of Accounting and Economics, 39 (2005), 487-507.

Finn, E., and E. Markus. Second Circuit Holds That Two Series of Common Stock Are Not Matchable Under the Short-Swing Profit Rule. Houston, TX: Andrews Kurth LLP (2013).

Fishe, R. P. H., and M. A. Robe. "The Impact of Illegal Insider Trading in Dealer and Specialist Markets: Evidence from a Natural Experiment." Journal of Financial Economics, 71 (2004), 461-488.

Fishman, M. J., and K. M. Hagerty. "Insider Trading and the Efficiency of Stock Prices." RAND Journal of Economics, 23 (1992), 106-122.

Fried, J. M. "Reducing the Profitability of Corporate Insider Trading through Pretrading Disclosure." Southern California Law Review, 71 (1997), 303-392.

Gibbons v. Malone. 801 F.Supp.2d 243 (S.D.N.Y. 2011). 
Glaeser, E. L., and A. Shleifer. "Legal Origins." Quarterly Journal of Economics, 117 (2002), 1193-1229.

Goldmark, J. A. "2nd Circuit Limits Short-Swing Insider Trading Claims.” Davis Wright Tremaine LLP (2013).

Goldstein, P. "Section 16(B) - If at First You Don't Succeed....” Working Paper, Harvard Law School Forum on Corporate Governance and Financial Regulation (2017).

Gompers, P. A.; J. Ishii; and A. Metrick. "Extreme Governance: An Analysis of Dual-Class Firms in the United States." Review of Financial Studies, 23 (2010), 1051-1088.

Hirshleifer, D.; S. S. Lim; and S. H. Teoh. "Driven to Distraction: Extraneous Events and Underreaction to Earnings News.” Journal of Finance, 64 (2009), 2289-2325.

Holmstrom, B., and S. N. Kaplan. "Corporate Governance and Merger Activity in the United States: Making Sense of the 1980s and 1990s." Journal of Economic Perspectives, 15 (2001), 121-144.

Ishizumi, K. "Insider Trading Regulation: An Examination of Section 16(b) and a Proposal for Japan." Fordham Law Review, 47 (1978), 449-494.

Jackson, H. E., and M. Roe. "Public and Private Enforcement of Securities Laws: Resource-Based Evidence." Journal of Financial Economics, 93 (2009), 207-238.

Jacobs, A. S. "An Analysis of Section 16 of the Securities Exchange Act of 1934." New York Law School Law Review, 32 (1987), 209-700.

Jagolinzer, A. D. "SEC Rule 10b5-1 and Insiders' Strategic Trade.” Management Science, 55 (2008), 224-239.

Jagolinzer, A. D.; D. F. Larcker; and D. J. Taylor. "Corporate Governance and the Information Content of Insider Trades." Journal of Accounting Research, 49 (2011), 1249-1274.

Jeng, L. A.; A. Metrick; and R. Zeckhauser. "Estimating the Returns to Insider Trading: A Performance-Evaluation Perspective." Review of Economics and Statistics, 85 (2003), 453-471.

Jennings, R. W.; H. Marsh; and J. C. Coffee. Securities Regulation: Cases and Materials. 7th ed. Westbury, NY: Foundation (1992).

Johnstone, S. "Why HK Class-Actions Are a Flawed Debate." International Financial Law Review, 34 (2015), 38-39.

Kahn, C., and A. Winton. "Ownership Structure, Speculation, and Shareholder Intervention.” Journal of Finance, 53 (1998), 99-129.

Ke, B.; S. Huddart; and K. Petroni. "What Insiders Know About Future Earnings and How They Use It: Evidence from Insider Trades." Journal of Accounting and Economics, 35 (2003), 315-346.

Kyle, A. S. "Continuous Auctions and Insider Trading." Econometrica, 53 (1985), 1315-1335.

La Porta, R.; F. Lopez-de-Silanes; A. Shleifer; and R. Vishny. "Law and Finance." Journal of Political Economy, 106 (1998), 1113-1155.

La Porta, R.; F. Lopez-de-Silanes; A. Shleifer; and R. Vishny. "Investor Protection and Corporate Governance." Journal of Financial Economics, 58 (2000), 3-27.

Lenkey, S. L. "Insider Trading and the Short-Swing Profit Rule." Journal of Economic Theory, 169 (2017), 517-545.

Liman, L. "Second Circuit Rules on Short-Swing Profit." White Paper, Harvard Law School Forum on Corporate Governance and Financial Regulation (2013).

Lowenfels, L. D. "Section 16(b) a New Trend in Regulating Insider Trading." Cornell Law Review, 54 (1968), 45-64.

Lowenfels, L. D. "Scienter or Negligence Required for SEC Injunctions under Section 10(b) and Rule 10b-5: A Fascinating Paradox.” Business Lawyer, 33 (1978), 789-809.

Macchiarola, M. C. "Tilting at Insider Trading Windmills." University of Pennsylvania Law Review Online, 163 (2014), 61-74.

Manne, H. G. Insider Trading and the Stock Market. New York, NY: Free Press (1966).

Manne, H. G. "Keynote Address." Journal of Law, Economics \& Policy, 4 (2008), 225-232.

Maug, E. G.; J. Van Halteren; and A. Ackerman. "Insider Trading Legislation and Acquisition Announcements: Do Laws Matter?" Working Paper, University of Mannheim (2008).

Munter, J. E. "Section 16(b) of the Securities Exchange Act of 1934: An Alternative to 'Burning Down the Barn in Order to Kill the Rats." Cornell Law Review, 52 (1966), 69-101.

Muth, K. T. "With Avarice Aforethought: Insider Trading and 10b5-1 Plans." U.C. Davis Business Law Journal, 10 (2009), 65-82.

O’Connor, M. A. “Toward a More Efficient Deterrence of Insider Trading: The Repeal of Section 16(b)." Fordham Law Review, 58 (1989), 309-381.

Richardson, S.; S. H. Teoh; and P. D. Wysocki. "The Walk-Down to Beatable Analyst Forecasts: The Role of Equity Issuance and Insider Trading Incentives." Contemporary Accounting Research, 21 (2004), 885-924.

Romeo, P. J., and A. L. Dye. "Developments Under Section 16 (Part I of Two Parts)." Review of Securities and Commodities Regulation, 33 (2000), 1-12. 
Roulstone, D. T. "The Relation between Insider-Trading Restrictions and Executive Compensation." Journal of Accounting Research, 41 (2003), 525-551.

Seligman, J. The Transformation of Wall Street: A History of the Securities and Exchange Commission and Modern Corporate Finance. 3rd ed. New York, NY: Aspen Publishers (2003).

Seyhun, H. N. "Insiders' Profits, Costs of Trading, and Market Efficiency." Journal of Financial Economics, 16 (1986), 189-212.

Seyhun, H. N. "The Effectiveness of the Insider-Trading Sanctions." Journal of Law and Economics, 35 (1992), 149-182.

Sharpe, W. F. "Capital Asset Prices: A Theory of Market Equilibrium under Conditions of Risk." Journal of Finance, 19 (1964), 425-442.

Shleifer, A., and R. Vishny. "A Survey of Corporate Governance." Journal of Finance, 52 (1997), 737-783.

Smolowe v. Delendo Corporation. 136 F.2d 231 (2d Cir. 1943).

Sokenuai, C. O.; S. J. Baskin; M. L. Craner; A. Dunogué; S. Fishbein; J. S. Fortinsky; J. J. Frank; A. S. Hakki; D. H. R. Laguardia; C. L. LaVigne; J. A. Nathanson; J. J. Resetarits; M. D. Lanpher; P. Urofsky; S. D. Hibbard; P. D. Robbins; and B. G. Burke. Securities Enforcement 2014 Year-End Review. New York, NY: Shearman \& Sterling LLP (2015).

Swanson, C. B. "Insider Trading Madness: Rule 10b5-1 and the Death of Scienter." University of Kansas Law Review, 52 (2003), 147-206.

Talesnick, A. L. "Corporate Silence and Rule 10b-5: Does a Publicly Held Corporation Have an Affirmative Obligation to Disclose?" Denver Law Journal, 49 (1972), 369-412.

Tamersoy, A.; E. Khalil; B. Xie; S. L. Lenkey; B. R. Routledge; D. H. Chau; and S. B. Navathe. "Large-Scale Insider Trading Analysis: Patterns and Discoveries." Social Network Analysis and Mining, 4 (2014), 1-17.

Taylor, E. “Teaching an Old Law New Tricks: Rethinking Section 16.” Arizona Law Review, 39 (1997), 1315-1359.

Wang, W.; Y. Shin; and B. B. Francis. "Are CFOs' Trades More Informative Than CEOs' Trades?" Journal of Financial and Quantitative Analysis, 47 (2012), 743-762. 